\title{
Review
}

\section{Control of body weight: a physiologic and transgenic perspective}

\author{
G. Frühbeck, J. Gómez-Ambrosi \\ Metabolic Research Laboratory, Clínica Universitaria de Navarra, University of Navarra, Pamplona, Spain
}

\section{Overview}

In mammals, body weight is normally regulated around a set point by coordinated changes in food intake and energy expenditure. These changes are integrated under the influence of specific neural pathways and circulating signals. Almost 50 years ago it was first proposed that circulating signals generated in proportion to body fat stores influence appetite and energy expenditure in a coordinated manner to regulate body weight [1]. Of particular historical value are the classic parabiosis experiments which provided evidence that such circulating signals exist [2].

The positional cloning of the mouse $o b$ gene and identification of its protein product, leptin, suggested that the long sought blood-borne lipostatic factor had
Received: 23 January 2003 / Revised: 23 January 2003

Published online: 15 February 2003

(C) Springer-Verlag 2003

Corresponding author: G. Frühbeck R Nutr MD PhD, Department of Endocrinology, Clínica Universitaria de Navarra, University of Navarra, Avda. Pío XII 36, 31008 Pamplona, Spain E-mail: gfruhbeck@unav.es

Tel.: +34-948-255400 ext. 4484, Fax: +34-948-296500

Abbreviations: $11 \beta$ HSD-1, $11 \beta$ hydroxysteroid dehydrogenase type $1 ; 5 \mathrm{HT}_{2 \mathrm{C}}-\mathrm{R}$, serotonin (5-hydroxytryptamine) $2 \mathrm{C}$ receptor; ACC, acetyl-CoA carboxylase; ADAM 12, member 12 of a disintegrin and metalloprotease family; ADAM 12-S, shorter secreted form of ADAM 12; AGRP, agouti related protein; AGT, angiotensinogen; ALBP, adipocyte lipid binding protein; aP2, adipocyte fatty acid binding protein; AR, adrenergic receptors; ASP, acylation-stimulating protein; BAT, brown adipose tissue; BRS-3, bombesin receptor subtype-3; C/EBP, CCAAT/enhancer binding protein; CART, cocaine- and amphetamine-regulated transcript; CCK, cholecystokinin; CCKA-R, cholecystokinin A receptor; CD36, (FAT) fatty acid translocase; CNS, central nervous system; $\mathrm{CRH}$, corticotropin-releasing hormone; DGAT, diacylglycerol acyltransferases; E2F, E2F transcription factor; Eif4ebp1, eukaryotic translation initiation factor $4 \mathrm{e}$ binding protein 1 ; ER- $\alpha$, estrogen receptor $\alpha$; FAS, fatty acid synthase; FGF, fibroblast growth factor; FIRKO, fatspecific insulin receptor knockout; FOXC2, forkhead box C2; GIP, glucose-dependent insulinotropic peptide; GIPr, GIP receptor; Gi $\alpha$, inhibitory G protein alpha-subunit; GLP-1, glucagon-like peptide-1; GLP-1R, GLP-1 receptor; GPAT, glycerol3-phosphate acyltransferase; GPDH, glycerol 3-phosphate dehydrogenase; Gs $\alpha$, stimulatory $\mathrm{G}$ protein alpha-subunit; Hmgic, high-mobility group phosphoprotein isoform I-C; HSL, hormone sensitive lipase; iNOS, inducible nitric oxide synthase; JAK, Janus kinases; LPL, lipoprotein lipase; MC3-R, melanocortin-3 receptor; MC4-R, melanocortin-4 receptor; MIRKO, muscle-specific insulin receptor knockout; mtGPAT, mitochondrial GPAT; MT-I and -II, metallothionein-I and -II; Nhlh2, nescient helix-loop-helix 2; NIRKO, neuron-specific insulin receptor knockout; NPY, neuropeptide Y; NPY1-R, neuropeptide Y-1 receptor; NPY2-R, neuropeptide Y-2 receptor; NPY4-R, neuropeptide Y-4 receptor; NPY5-R, neuropeptide Y-5 receptor; PAI-1, plasminogen activator inhibitor-1; PGC-1, PPAR $\gamma$ co-activator 1; POMC, pro-opiomelanocortin; PPAR, peroxisome proliferator-activated receptor; PTP-1B, protein tyrosine phosphatase $1 \mathrm{~B}$; RII $\beta$, regulatory subunit II $\beta$ of protein kinase A; RXR, retinoid X receptor; SF-1, steroidogenic factor 1; SIM1, single-minded 1; SREBP, sterol regulatory element binding protein; STAT, signal transducers and activators of transcription; Tg, transgenic; Th, tyrosine hydroxylase; TR $\alpha 2$, thyroid hormone receptor $\alpha 2$; UCP, uncoupling protein; UCP-DTA, uncoupling protein-promoter-driven diphtheria toxin A; Ucp-H, UCP1-High; Ucp-L, UCP1-Low; VGF, nerve growth factor induced protein; WAT, white adipose tissue; ZIP, leucine zipper transcription factor; $\alpha-\mathrm{MSH}$, melanocyte-stimulating hormone; $\beta$ IRKO, $\beta$-cell-specific insulin receptor knockout.

[Diabetologia (2003) 46:143-172

Keywords Lipostatic factors, energy balance, satiety, obesity, leptin, transgenesis. 
been found [3]. Leptin appeared to fulfill the predictions of the lipostatic hypothesis in that it is mainly produced by adipocytes, circulates in proportion to total adipose tissue mass, and interacts specifically with a hypothalamic receptor to reduce food intake and promote weight loss $[4,5]$. Paradoxically, almost one decade after the discovery of leptin it becomes clear that leptin alone does not explain all the outcomes of parabiotic studies. The evidence for the existence of additional adipostatic factors has already been reviewed $[6,7,8]$. With obesity as an increasingly important public health focus, a major development in the understanding of energy balance regulation has come with observations made in quite different biological spheres such as whole-body physiology and application of transgenic technology. Given that body weight regulation and food intake represent physiological processes that underpin both cell life and cell death, the presence of back-up mechanisms is not surprising. As with many biological systems, controversies and exceptions are not uncommon, especially to nascent pathways. Even in the age of molecular biotechnology there is a prominent role for physiological experimentation and reasoning in the discovery of important new regulatory and effector molecules.

Great progress has been made in identifying several genes in spontaneous monogenic animal models of obesity as well as in understanding the molecular mechanisms underlying phenotypes of altered body weight, adiposity and fat distribution by creating transgenic animal models (see reviews $[9,10,11]$ ). Targeted expression and knockout of specific genes has been extremely helpful in establishing the physiological roles of certain genes in the control of energy metabolism in vivo. Transgenic approaches, however, also have limitations [9]. Overexpression or knockout of concrete genes, and the subsequent alterations in the expression of their encoded proteins at different steps of the regulatory pathway of adipogenesis, show the complexity and complementarity of genes involved in energy homeostasis. In this sense, the failure to produce an expected phenotype through transgenesis further reflects the existence of adaptive mechanisms to preserve crucial physiological functions.

The analysis of a number of genetically obese mouse strains has clearly contributed to our understanding of body weight control. In particular, those strains that fail to synthesize either leptin or its functional receptor opened up the field to unravel the distinct metabolic abnormalities related to the development of an obese phenotype $[3,12,13,14]$. Of interest, the outcome of spontaneous mutations, transgenesis or knockout of specific genes can be subdivided in animal models leading to obesity, mouse strains characterised by leanness and manipulations conferring resistance to obesity (Tables 1, 2, 3). Mutations affecting not only neurotransmitters, neuropeptides and their receptors but also transcription factors, signal transducers, hormones, cytokines, adhesion molecules as well as enzymes and transporters involved in glucose and lipid metabolism play a key role in the development of an obese phenotype.

\section{Inputs to the CNS}

Melanocortins. A number of hypothalamic neurotransmitters and neuropeptides - including catecholamines, serotonin, leptin, AGRP, NPY, melanocytestimulating hormone $(\alpha-\mathrm{MSH})$, melanin-concentrating hormone, pro-opiomelanocortin (POMC), CART, CRH, and orexins, among others - have been implicated in the regulation of food intake and energy expenditure $[5,120,121]$. Leptin-responsive neurons in the arcuate nucleus include those expressing NPY-AGRP and POMC-CART. Both CART and $\alpha-M S H$, a cleavage product of POMC that stimulates melanocortin-3 and melanocortin-4 receptors (MC3-R and MC4-R), affect neurons of the paraventricular nucleus to decrease food consumption. Inactivation of MC3-R results in increased fat mass and reduced lean body mass despite hypophagia and normal metabolic rates $[39,40]$, whereas $M C 4-R^{-/-}$animals are characterised by obesity, mild hyperphagia and reduced energy expenditure [41]. Of interest, the double $M C 3-R^{-1-} M C 4-R^{-1-}$ mice have a more obese phenotype than MC4-R knockouts [39]. $P O M C^{-1-}$ rodents show obesity together with defective pigmentation and adrenal development [49]. Analogously, severe early-onset obesity, red hair pigmentation and adrenal insufficiency are observed in humans with POMC mutations [10].

It has been reported that obesity and yellow coat are two independent phenotypic features. Mice with the ele genotype, which prevents eumelanin synthesis, are yellow but non-obese, whereas $A^{v y}$ mice with a dominant sombre $\left(e^{s o}\right)$ gene, which prevents pheomelanin synthesis, are black yet obese [10, 11]. Moreover, inactivation of the MC1-R yields yellow but not obese rodents, whereas knockout of the $M C 4-R$ gene results in obese rodents without a yellow coat [51]. These observations suggest that MC4-R, highly expressed in the hypothalamus, is a key element in energy balance regulation and represents the link between the agouti mutation and the development of obesity.

A further piece to the puzzle of the complex relation between obesity and the agouti mutation has been provided by two autosomal recessive mutations, mahogany $(m g)$ and mahoganoid $(m d)$. Both mutations are able to revert agouti-induced obesity and restore melanogenesis. Except hyperphagia, homozygous mutations of the $m g$ gene prevent yellow fur coat colour change and obesity in $A^{y}$ mice by restoring normal body weight, adiposity, hyperglycaemia, hyperinsulinaemia, hyperleptinaemia and linear growth [111]. Since $m g$ is not able to reverse the phenotype of the $M C 1-R$ or MC4-R mutations, $m g$ action involves mo- 
Table 1. Rodent genetic models leading to obesity

\begin{tabular}{|c|c|c|c|c|c|}
\hline Model & Gene & Background $^{\mathrm{a}}$ & Genotype & Phenotype & Ref. \\
\hline $11 \beta$ HSD-1 Tg & $11 \beta H S D-1$ & FVB & $\begin{array}{l}\text { Transgenic overexpression } \\
\text { in adipose tissue }\end{array}$ & $\begin{array}{l}\text { Increased adipose concentrations } \\
\text { of corticosterone. Development } \\
\text { of visceral obesity that is } \\
\text { exaggerated by consumption of } \\
\text { a high-fat diet. Mice also show } \\
\text { pronounced insulin resistance, } \\
\text { hyperlipidaemia, and surprisingly } \\
\text { hyperphagia despite hyper- } \\
\text { leptinaemia }\end{array}$ & {$[15]$} \\
\hline $5 \mathrm{HT}_{2 \mathrm{C}}-\mathrm{R}$ deficient & $5 H T_{2 C}-R$ & 129/Sv x C57BL/6J & Knockout & $\begin{array}{l}\text { Overweight as a result of abnormal } \\
\text { control of feeding behaviour }\end{array}$ & [16] \\
\hline ADAM 12-S Tg & $A D A M 12$ & $\mathrm{C} 57 \mathrm{BL} / 6 \mathrm{~J} \times \mathrm{CBA}$ & $\begin{array}{l}\text { Transgenic overexpression } \\
\text { in skeletal muscle }\end{array}$ & $\begin{array}{l}\text { Increased body weight and total } \\
\text { body fat mass in females. Slight } \\
\text { overweight in males }\end{array}$ & {$[17]$} \\
\hline AGT Tg-WT & $A G T$ & B6/CBA x ICR-CD1 & $\begin{array}{l}\text { Transgenic overexpression } \\
\text { in adipose tissue }\end{array}$ & $\begin{array}{l}\text { Increased fat mass. High blood } \\
\text { pressure }\end{array}$ & [19] \\
\hline ArKO & $\begin{array}{l}\text { cyp } 19 \\
\text { (aromatase) }\end{array}$ & 129/Sv x C57BL/6J & Knockout & $\begin{array}{l}\text { Obesity. Reduced spontaneous } \\
\text { physical activity, reduced glucose } \\
\text { oxidation, and decreased lean } \\
\text { body mass }\end{array}$ & [20] \\
\hline$A^{y}$ & Agouti & $\mathrm{C} 57 \mathrm{BL} / 6 \mathrm{~J}$ & $\begin{array}{l}\text { Spontaneous dominant } \\
\text { mutation }\end{array}$ & $\begin{array}{l}\text { Variety of dominant mutations } \\
\text { known generally as yellow } \\
\text { mutation. Mutants show completely } \\
\text { yellow coat colour, obesity, an } \\
\text { insulin-resistant Type } 2 \text { diabetes, } \\
\text { and an increased propensity to } \\
\text { develop a variety of tumours }\end{array}$ & $\begin{array}{l}{[21,} \\
22]\end{array}$ \\
\hline$C O X-2^{+/-}$ & $C O X-2$ & C57/B6×129 Ola & Knockout & $\begin{array}{l}\text { Increased body weight due to } \\
\text { increased body fat }\end{array}$ & [24] \\
\hline$C p e^{f a t} / C p e^{f a t}$ & $C P E$ & HRS/J & $\begin{array}{l}\text { Spontaneous recessive } \\
\text { mutation }\end{array}$ & $\begin{array}{l}\text { Progressive adult onset obesity, } \\
\text { hyperinsulinaemia and infertility }\end{array}$ & $\begin{array}{l}{[25,} \\
26]\end{array}$ \\
\hline$f a / f a$ & Leptin- $R$ & $13 \mathrm{M}$ rat & $\begin{array}{l}\text { Spontaneous recessive } \\
\text { mutation }\end{array}$ & $\begin{array}{l}\text { Profound early-onset obesity } \\
\text { and Type } 2 \text { diabetes }\end{array}$ & $\begin{array}{l}{[27,} \\
28]\end{array}$ \\
\hline$f a^{k} / f a^{k}$ & Leptin- $R$ & SHR rat & $\begin{array}{l}\text { Spontaneous recessive } \\
\text { mutation }\end{array}$ & $\begin{array}{l}\text { Profound early-onset obesity and } \\
\text { Type } 2 \text { diabetes }\end{array}$ & [29] \\
\hline $\mathrm{FBH}$ & $B D N F$ & $129 \mathrm{SV}$ x C57B1/6 & Knockout & $\begin{array}{l}\text { Increased fat mass and body weight. } \\
\text { Hyperphagia and increased } \\
\text { locomotor activity }\end{array}$ & [30] \\
\hline FORKO & $F S H-R$ & 129SV x C57BL/6 & Knockout & $\begin{array}{l}\text { Loss of estrogen in the female null } \\
\text { mutants leads to obesity, increased } \\
\text { fat and skeletal abnormalities }\end{array}$ & {$[31]$} \\
\hline $\begin{array}{l}\text { GLUT4- } \\
\text { overexpressing } \\
\text { mice }\end{array}$ & GLUT4 & FVB & $\begin{array}{l}\text { Transgenic overexpression } \\
\text { in adipose tissue }\end{array}$ & $\begin{array}{l}\text { Increased fat mass as a con- } \\
\text { sequence of adipocyte hyperplasia. } \\
\text { Total bodylipid is increased } \\
\text { 2-3-fold }\end{array}$ & {$[32]$} \\
\hline
\end{tabular}


Table 1. (continued)

\begin{tabular}{|c|c|c|c|c|c|}
\hline Model & Gene & Background $^{\mathrm{a}}$ & Genotype & Phenotype & Ref. \\
\hline hGHRH Tg & $G H R H$ & C57BL/6 x SJL & $\begin{array}{l}\text { Transgenic overexpression } \\
\text { of human GHRH }\end{array}$ & $\begin{array}{l}\text { Increased amounts of abdominal } \\
\text { fat and hyperleptinaemia. } \\
\text { Normoglycaemia is achieved at } \\
\text { the expense of } 4.5 \text {-fold increased } \\
\text { concentrations of plasma insulin }\end{array}$ & {$[33]$} \\
\hline$I l 6^{-1-}$ & $I L-6$ & $\mathrm{C} 57 \mathrm{BL} / 6 \mathrm{~J}$ & Knockout & $\begin{array}{l}\text { Development of mature-onset } \\
\text { obesity with disturbed carbohydrate } \\
\text { and lipid metabolism, increased } \\
\text { leptin concentrations and decreased } \\
\text { responsiveness to leptin treatment }\end{array}$ & {$[35]$} \\
\hline $\begin{array}{l}L e p^{o b} / L e p^{o b} \\
(o b / o b)\end{array}$ & Leptin & C57BL/6J & $\begin{array}{l}\text { Spontaneous recessive } \\
\text { mutation }\end{array}$ & $\begin{array}{l}\text { Profound early-onset obesity and } \\
\text { Type } 2 \text { diabetes }\end{array}$ & $\begin{array}{l}{[3,} \\
12]\end{array}$ \\
\hline $\begin{array}{l}\text { Leprdb/Lepr }^{d b} \\
(d b / d b)\end{array}$ & Leptin-R & C57BL/Ks & $\begin{array}{l}\text { Spontaneous recessive } \\
\text { mutation }\end{array}$ & $\begin{array}{l}\text { Profound early-onset obesity and } \\
\text { Type } 2 \text { diabetes }\end{array}$ & $\begin{array}{l}{[13,} \\
14]\end{array}$ \\
\hline lit/lit & $G H$ & $129 / \mathrm{Sv} \times \mathrm{BALB} / \mathrm{c}$ & Knockout & $\begin{array}{l}\text { Despite a dramatic decrease in } \\
\text { body weight and skeletal growth, } \\
\text { a marked increase in percent body } \\
\text { fat is observed. No changes in food } \\
\text { consumption. Little knockout mice } \\
\text { are hypoglycaemic, but have normal } \\
\text { plasma insulin and corticosterone } \\
\text { concentrations }\end{array}$ & {$[38]$} \\
\hline$M C 3 R^{-/-} M C 4 R^{-/-}$ & $M C 3 R^{-1-}$ & $\mathrm{MC}_{4} \mathrm{R}^{-1-}$ & Intercrossing & Heavier than $M C 4 R^{-/-}$ & [39] \\
\hline$M C 4-R^{-1-}$ & $M C 4-R$ & 129/Sv x C57BL/6J & Knockout & $\begin{array}{l}\text { Maturity-onset obesity syndrome } \\
\text { associated with hyperphagia, } \\
\text { hyperinsulinaemia, } \\
\text { and hyperglycaemia }\end{array}$ & {$[41]$} \\
\hline MIRKO & Insulin- $R$ & C57BL/6J x FVB & $\begin{array}{l}\text { Specific disruption } \\
\text { of } I R \text { gene in muscle }\end{array}$ & $\begin{array}{l}\text { Increased fat mass, serum } \\
\text { triglycerides, and non-esterified } \\
\text { fatty acids, but normal blood } \\
\text { glucose, insulin, and glucose } \\
\text { tolerance }\end{array}$ & {$[42]$} \\
\hline MT-null & MT-I and -II & 129/Ola-C57BL/6J & Knockout & $\begin{array}{l}\text { Moderate obesity with higher food } \\
\text { intake, increased epididymal WAT } \\
\text { weights, as well as increased plasma } \\
\text { insulin and leptin concentrations }\end{array}$ & [43] \\
\hline Nhlh2-/- & Nhlh2 & 129/Sv x C57BL/6 & Knockout & $\begin{array}{l}\text { Progressive adult-onset obesity. } \\
\text { Hypogonadism }\end{array}$ & [44] \\
\hline NIRKO & Insulin- $R$ & C57BL/6J x FVB & $\begin{array}{l}\text { Neurone-specific } \\
\text { disruption of IR gene }\end{array}$ & $\begin{array}{l}\text { Female mice show increased food } \\
\text { intake. Both male and female mice } \\
\text { develop diet-sensitive obesity with } \\
\text { increases in body fat, mild insulin } \\
\text { resistance, increased plasma insulin } \\
\text { concentrations, and hypertriglycerid- } \\
\text { aemia }\end{array}$ & {$[45]$} \\
\hline
\end{tabular}


Table 1. (continued)

\begin{tabular}{|c|c|c|c|c|c|}
\hline Model & Gene & Background $^{\mathrm{a}}$ & Genotype & Phenotype & Ref. \\
\hline$o b / o b-a P 2^{-/-}$ & $a P 2$ & $o b / o b$ & Intercrossing & $\begin{array}{l}\text { Increased body weight as } \\
\text { compared to } o b / o b \text { mice. More } \\
\text { insulin-sensitive than } o b / o b\end{array}$ & [46] \\
\hline$O b R^{S y n I} K O$ & Leptin-R & C57BL/6 x CBA & $\begin{array}{l}\text { Selective deletion in } \\
\text { neurones }\end{array}$ & $\begin{array}{l}\text { Obesity in a lesser extent than } \\
O b R \text {-null mice. Slight glucose } \\
\text { intolerance in some cases }\end{array}$ & [47] \\
\hline $\mathrm{POMC}^{-/-}$ & POMC & $\begin{array}{l}\text { 129/SvEv x } \\
\text { C57BL/6J }\end{array}$ & Knockout & $\begin{array}{l}\text { Obesity, defective adrenal } \\
\text { development and altered } \\
\text { pigmentation }\end{array}$ & [49] \\
\hline SF-1 KO & $S F-1$ & C57BL/6J & Knockout & $\begin{array}{l}\text { Late-onset obesity. Adrenal and } \\
\text { gonadal agenesis, impaired } \\
\text { gonadotropin expression }\end{array}$ & [51] \\
\hline $\operatorname{Sim} 1^{+/-}$ & SIM1 & $\mathrm{C} 57 \mathrm{BL} / 6 \times 129 / \mathrm{Sv}$ & Knockout & $\begin{array}{l}\text { Early-onset obesity with increased } \\
\text { linear growth. Hyperinsulinaemia } \\
\text { and hyperleptinaemia. Hyperphagia } \\
\text { with normal energy expenditure }\end{array}$ & {$[52]$} \\
\hline$T R \alpha 2-/-$ & $T R \alpha 2$ & 129/Ola x BALB/c & Knockout & $\begin{array}{l}\text { Increased body fat content despite } \\
\text { reduced body weight. Late-onset } \\
\text { growth retardation }\end{array}$ & [55] \\
\hline Tubby & $T u b$ & C57BL/6J & $\begin{array}{l}\text { Spontaneous recessive } \\
\text { mutation }\end{array}$ & $\begin{array}{l}\text { Late-onset weight gain accompanied } \\
\text { by progressive retinal and cochlear } \\
\text { degeneration }\end{array}$ & [25] \\
\hline $\begin{array}{l}\text { Type II gluco- } \\
\text { corticoid-R } \\
\text { Transgenic }\end{array}$ & $\begin{array}{l}\text { Type II gluco- } \\
\text { corticoid-R }\end{array}$ & $\mathrm{C} 3 \mathrm{H} \times \mathrm{C} 57 \mathrm{BL} / 6 \mathrm{~F} 2$ & Partial knockout & $\begin{array}{l}\text { Increased body weight and plasma } \\
\text { ACTH and corticosterone } \\
\text { concentrations }\end{array}$ & {$[56]$} \\
\hline$U c p$-DTA & $\begin{array}{l}\text { Brown } \\
\text { adipose tissue } \\
(B A T)\end{array}$ & $\mathrm{FVB} / \mathrm{N}$ & Genetic ablation of BAT & Decreased brown fat and obesity & [57] \\
\hline$Y 1-R^{-/-}$ & $N P Y 1-R$ & 129/Sv x C57BL/6J & Knockout & $\begin{array}{l}\text { Moderate obesity and mild hyper- } \\
\text { insulinaemia without hyperphagia }\end{array}$ & [58] \\
\hline$Y 2^{-/-}$ & $N P Y 2-R$ & 129/SvJ x C57BL/6J & Knockout & $\begin{array}{l}\text { Increased body weight and food } \\
\text { intake. Reduced locomotor activity. } \\
\text { Increased heart rate }\end{array}$ & {$[59]$} \\
\hline$Y 4^{-/-}, o b / o b$ & $N P Y 4-R$ & $o b / o b$ & Intercrossing & $\begin{array}{l}\text { Increased body weight as compared } \\
\text { to } o b / o b \text { mice in males, but not in } \\
\text { females. Restoration of fertility in } \\
\text { both male and female mice }\end{array}$ & {$[60]$} \\
\hline
\end{tabular}


Table 1. (continued)

\begin{tabular}{|c|c|c|c|c|c|}
\hline Model & Gene & Background $^{\mathrm{a}}$ & Genotype & Phenotype & Ref. \\
\hline$Y 5-R-/-$ & $N P Y 5-R$ & 129/Sv x C57BL/6 & Knockout & $\begin{array}{l}\text { Mild late-onset obesity characterised } \\
\text { by increased body weight, food } \\
\text { intake and adiposity. show normal } \\
\text { sensitivity to leptin }\end{array}$ & [61] \\
\hline$\alpha$ ERKO & Estrogen-R $\alpha$ & C57BL/6J & Knockout & $\begin{array}{l}\text { Obesity due to adipocyte hyperplasia } \\
\text { and hypertrophy. Insulin resistance }\end{array}$ & {$[62]$} \\
\hline
\end{tabular}

a The background refers to the mouse strain unless otherwise indicated

Table 2. Rodent genetic models characterised by a lean phenotype

\begin{tabular}{|c|c|c|c|c|c|}
\hline Model & Gene & Background $^{\mathrm{a}}$ & Genotype & Phenotype & Ref. \\
\hline$a b^{J} / a b^{J}$ & $S C D-1$ & $\mathrm{BALB} / \mathrm{cJ}$ & $\begin{array}{l}\text { Spontaneous recessive } \\
\text { mutation }\end{array}$ & $\begin{array}{l}\text { Decreased fat mass in males and } \\
\text { females. Increased body weight in } \\
\text { females }\end{array}$ & [64] \\
\hline$A c c 2^{-/-}$ & $A C C 2$ & mice & Knockout & $\begin{array}{l}\text { Higher fatty acid oxidation rate; } \\
50 \% \text { less fat content in adipose } \\
\text { tissue than wild-type mice }\end{array}$ & [65] \\
\hline anx/anx & Unknown & $\begin{array}{l}\text { C57BL/6JLe x } \\
\text { C3HeB/FeJLe }\end{array}$ & $\begin{array}{l}\text { Spontaneous recessive } \\
\text { mutation }\end{array}$ & $\begin{array}{l}\text { Growth failure, an emaciated } \\
\text { appearance, and abnormal } \\
\text { behaviour including headweaving, } \\
\text { body tremors, uncoordinated gait, } \\
\text { and hyperactivity during the late } \\
\text { pre-weanling period. Data suggest } \\
\text { that mutant mice are not ingesting } \\
\text { the amount of nutrients necessary } \\
\text { to sustain life }\end{array}$ & [66] \\
\hline$a P 2-S R E B P-1 c 436$ & $n S R E B P-1 c$ & C57BL/6J × SJL F1 & $\begin{array}{l}\text { Transgenic overexpression } \\
\text { in WAT }\end{array}$ & $\begin{array}{l}\text { White adipocytes failed to } \\
\text { differentiate fully, and the size of } \\
\text { white fat depots was markedly } \\
\text { decreased. Brown fat was hyper- } \\
\text { trophic and contained fat-laden } \\
\text { cells resembling immature white } \\
\text { fat. Marked insulin resistance with } \\
\text { increased blood glucose con- } \\
\text { centrations. These mice show many } \\
\text { of the features of human congenital } \\
\text { generalised lipodystrophy }\end{array}$ & [67] \\
\hline
\end{tabular}


Table 2. (continued)

\begin{tabular}{|c|c|c|c|c|c|}
\hline Model & Gene & Background $^{\mathrm{a}}$ & Genotype & Phenotype & Ref. \\
\hline C3(-/-) & $A S P$ & 129/Sv x C57BL/6 & Knockout & $\begin{array}{l}\text { Decreased body weight and fat mass. } \\
\text { Lower concentrations of glucose, } \\
\text { insulin and leptin }\end{array}$ & {$[70]$} \\
\hline Cav-1-/- & Caveolin-1 & C57BL/6 x sv129 & Knockout & $\begin{array}{l}\text { Decreased body weight compared } \\
\text { with wild-type controls at } 1 \text { year of } \\
\text { age. Aberrant endothelial cell } \\
\text { function }\end{array}$ & [71] \\
\hline$C / E B P \alpha^{-1-}$ & $C / E B P \alpha$ & $129 \mathrm{~Sv} \times \mathrm{CBA} / \mathrm{C} 57 \mathrm{Bl}$ & Knockout & $\begin{array}{l}\text { Fail to accumulate lipids in adipo- } \\
\text { cytes and liver and glycogen in } \\
\text { liver. Die in hours after birth }\end{array}$ & {$[72]$} \\
\hline$C / E B P \beta^{-/-}$ & $C / E B P \beta$ & C57BL/6 & Knockout & $\begin{array}{l}\text { High mortality after birth. Normal } \\
\text { body weight. Reduced fat pad } \\
\text { weights }\end{array}$ & [73] \\
\hline$C / E B P \delta^{-/-}$ & $C / E B P \delta$ & C57BL/6 & Knockout & $\begin{array}{l}\text { Normal body weight. Reduced fat } \\
\text { pad weights }\end{array}$ & [73] \\
\hline Crebbp $p^{+/-}$ & Crebbp & C57BL/6 x CBA & Knockout & $\begin{array}{l}\text { Markedly reduced weight of WAT } \\
\text { but not of other tissues. Increased } \\
\text { insulin sensitivity }\end{array}$ & {$[74]$} \\
\hline Eif4ebp1-1- & $4 E-B P 1$ & $129 / \mathrm{Sv} \times \mathrm{BALB} / \mathrm{c}$ & Knockout & $\begin{array}{l}\text { Markedly smaller white fat pads } \\
\text { than wild-type animals and } \\
\text { increased metabolic rate }\end{array}$ & {$[75]$} \\
\hline FIRKO & Insulin- $R$ & $\begin{array}{l}129 \mathrm{~Sv} \times \mathrm{C} 57 \mathrm{BL} / 6 \\
\mathrm{x} \mathrm{FVB}\end{array}$ & $\begin{array}{l}\text { Specific disruption of } I R \\
\text { gene in adipose tissue }\end{array}$ & $\begin{array}{l}\text { Lower body weight and fat mass. } \\
\text { Loss of the normal relationship } \\
\text { between plasma leptin and body } \\
\text { weight. Normal insulin sensitivity } \\
\text { and glucose homeostasis }\end{array}$ & [76] \\
\hline GLUT4-null & GLUT4 & 129/Sv x C57BL/6 & Knockout & $\begin{array}{l}\text { Growth-retardation and decreased } \\
\text { longevity associated with cardiac } \\
\text { hypertrophy and severely reduced } \\
\text { adipose tissue depots. Sexual } \\
\text { dimorphism in glucose metabolism. } \\
\text { Postprandial hyperinsulinaemia }\end{array}$ & [79] \\
\hline$G R^{\text {NesCre }}$ & $G R$ & BL6/SJF2 & $\begin{array}{l}\text { Specific disruption of } \\
G R \text { gene in the nervous } \\
\text { system }\end{array}$ & $\begin{array}{l}\text { Marked growth retardation. Lower } \\
\text { body weight and fat mass. metabolic } \\
\text { Decreased food intake and efficiency }\end{array}$ & [80] \\
\hline Hmgic $^{-/-}$ & Hmgic & $\mathrm{AB} 1 \times \mathrm{C} 57 \mathrm{BL} / 6 \mathrm{~J}$ & Knockout & Decreased body weight and fat mass & {$[81]$} \\
\hline$H Y P C R E-Y 2^{\text {lox/lox }}$ & $N P Y 2-R$ & 129/SvJ x C57BL/6J & $\begin{array}{l}\text { Selective deletion in } \\
\text { hypothalamus }\end{array}$ & $\begin{array}{l}\text { Decreased body weight and } \\
\text { adiposity and increased food intake. } \\
\text { Raised concentrations of PP. } \\
\text { Increased hypothalamic expression } \\
\text { of NPY, AGRP, and reduced } \\
\text { expression of POMC, and CART }\end{array}$ & [82] \\
\hline$I L-1 r a^{-/-}$ & $I L-1 r a$ & $129 / \mathrm{Sv}$ x C57BL/6J & Knockout & $\begin{array}{l}\text { Decreased body mass compared } \\
\text { with wild-type controls. Increased } \\
\text { susceptibility to lethal endotoxemia } \\
\text { than controls }\end{array}$ & {$[83]$} \\
\hline
\end{tabular}


Table 2. (continued)

\begin{tabular}{|c|c|c|c|c|c|}
\hline Model & Gene & Background ${ }^{\mathrm{a}}$ & Genotype & Phenotype & Ref. \\
\hline$M 3 R^{-1-}$ & $\begin{array}{l}\text { M3 } \\
\text { muscarinic } R\end{array}$ & 129/Sv x C57BL/6J & Knockout & $\begin{array}{l}\text { Reduced food intake, body weight } \\
\text { and peripheral fat depots. Very low } \\
\text { concentrations of serum leptin and } \\
\text { insulin }\end{array}$ & {$[84]$} \\
\hline $\mathrm{MCH}^{-/-}$ & $M C H$ & 129/Sv x C57BL/6J & Knockout & $\begin{array}{l}\text { Reduced body weight and leanness } \\
\text { due to hypophagia and an inappro- } \\
\text { priately increased metabolic rate }\end{array}$ & {$[85]$} \\
\hline$M \operatorname{ch} 1 r^{-/-}$ & $M C H 1 R$ & $129 / \mathrm{Sv} \times \mathrm{C} 57 \mathrm{BL} / 6 \mathrm{~J}$ & Knockout & $\begin{array}{l}\text { Hyperphagia and reduced fat mass } \\
\text { as a consequence of hyperactivity } \\
\text { and altered metabolism }\end{array}$ & {$[86]$} \\
\hline$M C K-C D 36$ & $C D 36$ & FVB & $\begin{array}{l}\text { Transgenic overexpression } \\
\text { in skeletal muscle }\end{array}$ & $\begin{array}{l}\text { Lower body weight than controls. } \\
\text { Reduced overall adipose tissue. } \\
\text { Lower concentrations of triglyc- } \\
\text { erides and fatty acids. Slight hyper- } \\
\text { glycaemia and hyperinsulinaemia }\end{array}$ & [87] \\
\hline$M_{s t n}^{-1-}$ & Myostatin & 129/Sv x C57BL/6J & Knockout & $\begin{array}{l}\text { Increase in skeletal muscle mass. } \\
\text { Significant reduction in fat } \\
\text { accumulation and a slightly } \\
\text { decreased resting metabolic rate }\end{array}$ & {$[89]$} \\
\hline$P E P C K-T G F-\beta 1$ & $T G F-\beta 1$ & C57Bl/6 x SJL & $\begin{array}{l}\text { Transgenic overexpression } \\
\text { in liver, kidney, } \\
\text { and adipose tissue }\end{array}$ & $\begin{array}{l}\text { Lipodystrophy-like syndrome. } \\
\text { All white fat depots and brown } \\
\text { fat pads are severely reduced in size, } \\
\text { and show prominent fibroplasia. } \\
\text { This reduction in WAT is due to } \\
\text { impaired adipose accretion }\end{array}$ & {$[90]$} \\
\hline PP transgenic & $P P$ & $\mathrm{BDF} 1 \times \mathrm{C} 57 \mathrm{BL} / 6 \mathrm{~J}$ & $\begin{array}{l}\text { Transgenic overexpression } \\
\text { in pancreatic islets }\end{array}$ & $\begin{array}{l}\text { Postnatal lethality in half of the } \\
\text { pups because of markedly decreased } \\
\text { milk intake. The remaining PP } \\
\text { transgenic mice gained less weight } \\
\text { with specifically reduced food intake } \\
\text { and fat mass compared with controls, } \\
\text { a result that was more evident in male } \\
\text { than in female mice. The transgenic } \\
\text { mice showed a reduced rate of gastric } \\
\text { emptying of a solid meal but had } \\
\text { normal oxygen consumption and } \\
\text { fasting leptin concentrations }\end{array}$ & [93] \\
\hline RII $\beta$ null mutant & $R I I \beta$ & 129/Sv x C57BL/6J & Knockout & $\begin{array}{l}\text { Markedly diminished WAT despite } \\
\text { normal food intake }\end{array}$ & [94] \\
\hline Stat5ab-/- & STAT5 $a \& b$ & 129/SvE x C57BL/6 & Knockout & Reduced body weight and body fat & [95] \\
\hline$T N F-\alpha-/-$ & $T N F-\alpha$ & C57BL/6×129 & Knockout & $\begin{array}{l}\text { Decreased body weight and fat mass. } \\
\text { Reductions in insulin, triglycerides, } \\
\text { and leptin concentrations }\end{array}$ & [96] \\
\hline Transgenic skinny & Leptin & $\mathrm{ICR}$ & $\begin{array}{l}\text { Transgenic overexpression } \\
\text { in liver }\end{array}$ & $\begin{array}{l}\text { Complete disappearance of white } \\
\text { and brown adipose tissue. Increased } \\
\text { glucose metabolism accompanied } \\
\text { by activation of insulin signalling. } \\
\text { Small-sized liver }\end{array}$ & {$[97]$} \\
\hline
\end{tabular}


Table 2. (continued)

\begin{tabular}{|c|c|c|c|c|c|}
\hline Model & Gene & Background ${ }^{\mathrm{a}}$ & Genotype & Phenotype & Ref \\
\hline$U c p-3 \operatorname{tg}$ & $U C P 3$ & $\mathrm{C} 57 \mathrm{BL} / 6 \times \mathrm{CBA}$ & $\begin{array}{l}\text { Transgenic overexpression } \\
\text { in skeletal muscle }\end{array}$ & $\begin{array}{l}\text { Hyperphagia but decreased body } \\
\text { weight compared to wild-type } \\
\text { littermates. Reduced adipose tissue } \\
\text { mass. Lower fasting plasma glucose } \\
\text { and insulin concentrations and } \\
\text { increased glucose clearance rate }\end{array}$ & {$[98]$} \\
\hline Ucp-L \& Ucp-H & $U C P 1$ & C57BL/6 x CBA & $\begin{array}{l}\text { Transgenic expression in } \\
\text { skeletal muscle }\end{array}$ & $\begin{array}{l}\text { Increased oxygen consumption in } \\
\text { skeletal muscle. Lower body weight } \\
\text { and glucose and triglycerides } \\
\text { concentrations than wild type }\end{array}$ & {$[100]$} \\
\hline$V g f^{\prime-}$ & $V G F$ & 129/SvJ x C57BL/6 & Knockout & $\begin{array}{l}\text { Decreased body size accompanied } \\
\text { by hypermetabolism, hyperactivity, } \\
\text { and infertility, with markedly } \\
\text { reduced leptin concentrations and } \\
\text { fat stores }\end{array}$ & {$[101]$} \\
\hline$V L D L R^{-/-}$ & $V L D L-R$ & 129/Sv x C57BL/6J & Knockout & $\begin{array}{l}\text { Decrease in body weight, body } \\
\text { mass index, and adipose tissue mass } \\
\text { as determined by the weights of } \\
\text { epididymal fat pads }\end{array}$ & {$[102]$} \\
\hline$Y 2^{-/-}$ & $N P Y 2-R$ & 129/SvJ x C57BL/6J & Knockout & $\begin{array}{l}\text { Decreased body weight and increased } \\
\text { food intake. Raised concentrations } \\
\text { of PP and corticosterone. Increased } \\
\text { hypothalamic expression of NPY, } \\
\text { AGRP, POMC, and CART }\end{array}$ & {$[82]$} \\
\hline
\end{tabular}

a The background refers to the mouse strain unless otherwise indicated

Table 3. Rodent genetic models conferring resistance to obesity

\begin{tabular}{|c|c|c|c|c|c|}
\hline Model & Gene & Background $^{\mathrm{a}}$ & Genotype & Phenotype & Ref. \\
\hline$a b^{J} / a b^{J} ; o b / o b$ & $S C D-1$ & $o b / o b$ & Intercrossing & $\begin{array}{l}\text { Dramatic reduction in body weight. } \\
\text { Reduced fat mass }\end{array}$ & [64] \\
\hline$a g t-1-$ & $A G T$ & ICR & Knockout & $\begin{array}{l}\text { Less weight gain than wild-type } \\
\text { mice in response to high-fat diet. } \\
\text { Decreased lipogenesis and increased } \\
\text { locomotor activity }\end{array}$ & [103] \\
\hline Cav-1-/- & Caveolin-1 & C57BL/6 x sv129 & Knockout & $\begin{array}{l}\text { Overt resistance to high-fat diet- } \\
\text { induced obesity despite hyperphagia }\end{array}$ & [71] \\
\hline Crebbp ${ }^{+/-}$ & Crebbp & C57BL/6 x CBA & Knockout & $\begin{array}{l}\text { Protection from weight gain } \\
\text { induced by a high-fat diet }\end{array}$ & [74] \\
\hline
\end{tabular}


Table 3. (continued)

\begin{tabular}{|c|c|c|c|c|c|}
\hline Model & Gene & Background $^{\mathrm{a}}$ & Genotype & Phenotype & Ref. \\
\hline $\mathrm{Dgat}^{-/-}$ & $D G A T$ & $\begin{array}{l}\text { C57BL/6J x } \\
\text { 129/SvJae }\end{array}$ & Knockout & $\begin{array}{l}\text { Resistance to diet-induced obesity } \\
\text { by increasing energy expenditure } \\
\text { and activity }\end{array}$ & {$[105]$} \\
\hline$E 2 F 1^{-/-}$ & $E 2 F 1$ & 129/SvJ x C57BL/6J & Knockout & $\begin{array}{l}\text { Resistance to obesity induced by } \\
\text { high-fat diet which could be entirely } \\
\text { attributed to differences in fat mass }\end{array}$ & [106] \\
\hline Foxc2 tg & $F O X C 2$ & C57BL/6J x CBA & $\begin{array}{l}\text { Transgenic overexpression } \\
\text { in adipocytes }\end{array}$ & $\begin{array}{l}\text { Reversal of most obesity-associated } \\
\text { symptoms, including hypertriglycerid- } \\
\text { aemia and insulin-resistance }\end{array}$ & [77] \\
\hline $\begin{array}{l}\text { Giprr }^{-/-} \\
\text {Lep }^{o b} / \text { Lep }^{o b}\end{array}$ & $G I P r$ & $o b / o b$ & Intercrossing & $\begin{array}{l}\text { Gain less weight and have lower } \\
\text { adiposity than } o b / o b \text { mice }\end{array}$ & [107] \\
\hline$G L P-1 R^{-/-}$ & $G L P-1 R$ & 129/SV x CD1 & Knockout & $\begin{array}{l}\text { Resistance to high-fat diet-induced } \\
\text { obesity in females, but not in males }\end{array}$ & [108] \\
\hline Hmgic $^{-/-}$ & Hmgic & $\mathrm{AB} 1 \times \mathrm{C} 57 \mathrm{BL} / 6 \mathrm{~J}$ & Knockout & $\begin{array}{l}\text { Resistance to high-fat diet-induced } \\
\text { obesity }\end{array}$ & {$[81]$} \\
\hline $\begin{array}{l}\text { Hmgic }^{-/-} \\
\text {Lep }^{o b} / \text { Lep }^{o b}\end{array}$ & Hmgic & $o b / o b$ & Intercrossing & $\begin{array}{l}\text { Gene-dose-dependent reduction in } \\
\text { obesity induced by leptin deficiency }\end{array}$ & {$[81]$} \\
\hline$M \operatorname{chl} 1 r^{-/-}$ & $M C H 1 R$ & 129/Sv x C57BL/6J & Knockout & $\begin{array}{l}\text { Low susceptibility to diet-induced } \\
\text { obesity }\end{array}$ & {$[86]$} \\
\hline$m g / m g A^{y / a}$ & Mahogany & $A^{y}$ & Intercrossing & $\begin{array}{l}m g / m g \text { blocks obesity, hyperinsulin- } \\
\text { aemia, and increased linear growth } \\
\text { induced by the } A^{y} \text { mutation }\end{array}$ & {$[111]$} \\
\hline$M s t n^{-/} A^{y}$ & Myostatin & $A^{y}$ & Intercrossing & $\begin{array}{l}\text { Partial suppression of fat } \\
\text { accumulation and of abnormal } \\
\text { glucose metabolism }\end{array}$ & [89] \\
\hline$M s t n^{-/} o b / o b$ & Myostatin & $o b / o b$ & Intercrossing & $\begin{array}{l}\text { Partial suppression of fat } \\
\text { accumulation and amelioration } \\
\text { of abnormal glucose metabolism }\end{array}$ & [89] \\
\hline$N P Y^{-/-} o b / o b$ & $N P Y$ & $o b / o b$ & Intercrossing & $\begin{array}{l}\text { Attenuation of obesity due to } \\
\text { reduced food intake and increased } \\
\text { energy expenditure. Improvement } \\
\text { in diabetes, sterility, and somato- } \\
\text { tropic defects compared to } o b / o b \\
\text { mice }\end{array}$ & [112] \\
\hline$p 75^{-/-}$ & $\begin{array}{l}\text { p75 } \\
(T N F \alpha-R)\end{array}$ & $\mathrm{C} 57 \mathrm{BL} / 6 \times 129$ & Knockout & $\begin{array}{l}\text { Decreased body weight and leptin } \\
\text { concentrations as well as improved } \\
\text { insulin sensitivity compared to wild } \\
\text { type mice on a high-fat diet }\end{array}$ & [113] \\
\hline
\end{tabular}


Table 3. (continued)

\begin{tabular}{|c|c|c|c|c|c|}
\hline Model & Gene & Background $^{\mathrm{a}}$ & Genotype & Phenotype & Ref. \\
\hline$P A I-1^{-/-} o b / o b$ & $P A I-1$ & $o b / o b$ & Intercrossing & $\begin{array}{l}\text { Reduced adiposity and improved } \\
\text { metabolic profile as compared } \\
\text { to } o b / o b\end{array}$ & {$[114]$} \\
\hline Plin $^{-/-}$or peri ${ }^{-/-}$ & Perilipin & 129/Sv x C57BL/6J & Knockout & Resistance to diet-induced obesity & {$[91,92]$} \\
\hline Plin-/- db/db & Perilipin & $d b / d b$ & Intercrossing & $\begin{array}{l}\text { Reversal of the } d b / d b \text { obese pheno- } \\
\text { type by increasing the metabolic } \\
\text { rate of mice }\end{array}$ & {$[91]$} \\
\hline$P P A R \gamma^{+/-}$ & $P P A R \gamma$ & Balb/c x ICR & Knockout & $\begin{array}{l}\text { Resistant to increased fat mass and } \\
\text { fatty liver under a high-fat diet. } \\
\text { Protection from high-fat diet- } \\
\text { induced insulin resistance by } \\
\text { prevention of adipocyte hypertrophy }\end{array}$ & {$[115]$} \\
\hline$P T P 1 B^{-/-} L e p^{o b / o b}$ & $P T P-1 B$ & $o b / o b$ & Intercrossing & $\begin{array}{l}\text { Attenuated weight gain, decreased } \\
\text { adipose tissue, and increased resting } \\
\text { metabolic rate }\end{array}$ & {$[117]$} \\
\hline RII $\beta$ null mutant & $R I I \beta$ & 129/Sv x C57BL/6J & Knockout & $\begin{array}{l}\text { Protection against diet-induced } \\
\text { obesity and fatty liver }\end{array}$ & {$[94]$} \\
\hline$T G F-\beta 1: o b / o b$ & $T G F-\beta 1$ & $o b / o b$ & Intercrossing & $\begin{array}{l}\text { Reversal of the } o b / o b \text { obesity } \\
\text { phenotype; however, transgenic } \\
\text { mutant mice developed severe } \\
\text { hepato- and splenomegaly }\end{array}$ & {$[90]$} \\
\hline$U c p-L \& U c p-H$ & $U C P 1$ & C57BL/6 x CBA & $\begin{array}{l}\text { Transgenic expression } \\
\text { in skeletal muscle }\end{array}$ & $\begin{array}{l}\text { Resistance to obesity induced by } \\
\text { high-fat diets. Reduction in } \\
\text { adiposity and lower concentrations } \\
\text { of glucose, insulin and cholesterol. } \\
\text { Increased metabolic rate at rest } \\
\text { and with exercise }\end{array}$ & {$[100]$} \\
\hline$V L D L R^{-1-} o b / o b$ & $V L D L-R$ & $o b / o b$ & Intercrossing & $\begin{array}{l}\text { Decreased weight gain compared } \\
\text { to ob/ob mice. Reduction in both } \\
\text { subcutaneous and visceral adipose } \\
\text { tissue mass due to smaller adipocytes }\end{array}$ & [118] \\
\hline$Y 5 R-/-; o b / o b$ & $N P Y 5-R$ & $o b / o b$ & Intercrossing & Equally obese than $o b / o b$ mice. & {$[61]$} \\
\hline$\beta_{1} A R \mathrm{Tg}$ & $\beta_{1}-A R$ & Swiss-Webster & $\begin{array}{l}\text { Transgenic overexpression } \\
\text { in adipocytes }\end{array}$ & $\begin{array}{l}\text { Transgenic animals were partially } \\
\text { resistant to diet-induced obesity } \\
\text { showing smaller adipose tissue } \\
\text { depots than their nontransgenic } \\
\text { littermates, due to decreased lipid } \\
\text { accumulation in adipocytes }\end{array}$ & [119] \\
\hline
\end{tabular}

lecular events downstream of the $A^{y}$ mutation, but upstream of the melanocortin receptors [10].

Several neurotransmitters play a key role in feeding behaviour [5, 121] as shown for increases in brain serotonin, which decreases food intake. Mice lacking the $5 \mathrm{HT}_{2 \mathrm{c}}$ receptor subtype have a normal body weight at younger ages. However, late-onset obesity with an increase in WAT mass takes place due to hyperphagia $[10,16]$. Fenfluramine, a once widely prescribed appetite supressant, stimulates the release of serotonin in the arcuate nucleus of the hypothalamus binding to $5 \mathrm{HT}_{2 \mathrm{c}}$ receptors expressed in POMC neurons. In turn they stimulate the release of $\alpha-\mathrm{MSH}$ that subsequently acts on effector neurons expressing MC3-R and MC4-R, which have been identified as critical regulators of food intake and energy homeostasis [122]. Use of gene knockout technology has shown that dopamine is required for hyperphagia in $o b / o b$ mice and that dopamine-deficient mice have a smaller size 2 weeks postnatally with a negative 
growth rate leading to death at around 1 month of age in relation to decreased eating and drinking behaviour [104].

Neuropeptide. $Y$ NPY is a widely expressed neuropeptide with biological functions including food intake stimulation and control of autonomic and endocrine actions aimed at sparing energy and regulating the cardiovascular, cortical and sympathetic nervous systems [10]. Lack of NPY results in normal weight animals with normal appetite under physiological circumstances, but with a hyperphagic response to fasting. Mice remained leptin-responsive even with hypersensitivity to leptin-mediated inhibition of feeding. A role for NPY in leptin action was shown by the generation of a double knockout lacking both NPY and leptin [112]. Compared to ob/ob mice the simultaneous deficiency of NPY resulted in an intermediary obese phenotype showing reduced adiposity, and food intake together with improved fertility, increased oxygen consumption, locomotor activity and body temperature [112]. Thus, both anabolic NPY-containing and catabolic POMC-containing neurons are direct targets of leptin action. The orexigenic effects of NPY have been reportedly assigned to binding to $\mathrm{Y} 1$ and $Y 5$ receptors [9]. However, $Y 1, Y 2, Y 4$ and $Y 5$ receptor knockouts show obesity $[9,58,59,60,61,82] . Y^{-1}$ mice show a markedly reduced feeding response to fasting and slightly decreased daily food intake and NPY-stimulated feeding while $Y 5 R^{-1-}$ rodents have a normal feeding response to fasting and leptin but markedly reduced to NPY stimulation. They develop late-onset obesity associated with hyperphagia in the case of Y5R-deficient animals, or lowered metabolic rate associated to hypoactivity or changes in UCP gene expression in the case of $Y 1 R$ mutants [9, 61]. Mice lacking Y2R also develop mild obesity due to hyperphagia, therefore normal feeding behaviour, body weight and leptin response require Y2R [59].

Others. A number of factors such as nescient helixloop-helix 2 (Nhlh2), single-minded 1 (SIM1), steroidogenic factor 1 (SF-1) and nerve growth factorinduced protein (VGF) involved in CNS development have also been implicated in body weight regulation [10]. Homozygotes for Nhlh2 suffer from hypogonadism associated to a reduced fertility [44]. Approximately 10 to 15 weeks after birth extreme obesity becomes evident. This characteristic phenotype shows that the Nhlh gene is necessary for the adequate development of the hypothalamic-pituitary axis and that part of the obesity seems to be independent of the hypogonadism being directly linked to a defect in hypothalamic development [10]. Mice in which SIM1 is deleted lack CRH, oxytocin, vasopressin, somatostatin and thyrotropin-releasing hormone and die shortly after birth. In humans haploinsufficiency of the SIMI gene has resulted in early onset obesity with increased adiposity and hyperphagia despite apparently normal metabolic and hormonal variables [52]. SF-1 knockout mice suffer from infertility and inadequate development of the hypothalamic ventromedial nucleus and the adrenal glands [51]. Mice lacking the expression of $V g f$ are of a small size a few days after birth due to a decrease in body fat, which is not attributable to decreased food intake [101]. Characteristic features of $V g f$-null mice are hyperactivity, augmented energy expenditure and infertility with low plasma concentrations of glucose, insulin and leptin.

\section{Transcriptional regulation}

Numerous transcription factors have been reported to regulate adipocyte proliferation and differentiation [10, 11] (Fig. 1).

CCAAT/enhancer-binding protein. Knockouts of the CCAAT/enhancer-binding protein $(\mathrm{C} / \mathrm{EBP}) \alpha, \beta$, and $\delta$ result in partial or complete lack of adipocytic lipid accumulation $[72,73]$. $\mathrm{C} / \mathrm{EBP} \alpha$ is required for the differentiation of preadipocytes to mature adipocytes in most WAT depots. However, it is not indispensable for BAT and mammary gland WAT development. Mice lacking $\mathrm{C} / \mathrm{EBP} \beta$ and/or $\delta$ show a severe phenotype with decreased fat pad weights due to a lower number of adipocytes tributary to the incompetence of embryonic fibroblasts to differentiate into adipocytes. Furthermore, fibroblasts derived from $\mathrm{C} / \mathrm{EBP} \beta$ and/or $\delta$ null mice do not express $\mathrm{C} / \mathrm{EBP} \alpha$ and PPAR $\gamma$ [11]. These animal models show the ocurrence of cross-talk between C/EBP $\alpha$ and PPAR $\gamma$ and suggest the existence of alternative pathways in vivo to compensate for the lack of $\mathrm{C} / \mathrm{EBP} \beta$ and/or $\delta$ in null mice. The role of $\mathrm{C} / \mathrm{EBP}$ in adipocyte development is further supported by A-ZIP/F transgenic mice. Overexpression of the $A-Z I P / F$ gene whose product inactivates, among others, the C/EBP family, renders a phenotype that is virtually fat-depleted, thus showing very low energy reserves with no WAT and a reduced amount of BAT [69].

Peroxisome proliferator-activated receptor. Many lipid factors such as ceramides, gangliosides, sphingolipids, prostaglandins, eicosanoids, and sterols are known activators or ligands of the PPARs. The study of their molecular and physiological characteristics has shown their involvement in many physiological functions including energy balance and adipocyte differentiation. Thus the lack of PPAR $\alpha$ disrupts fatty acid oxidation in the liver leading to an increased WAT deposition [50], whereas the ubiquitously expressed PPAR $\beta$, also termed $\delta$, seems to play a role in adipocyte differentiation with null mice showing a normal development except for a smaller size [11, 123]. The reduction in fat-pad mass observed in 


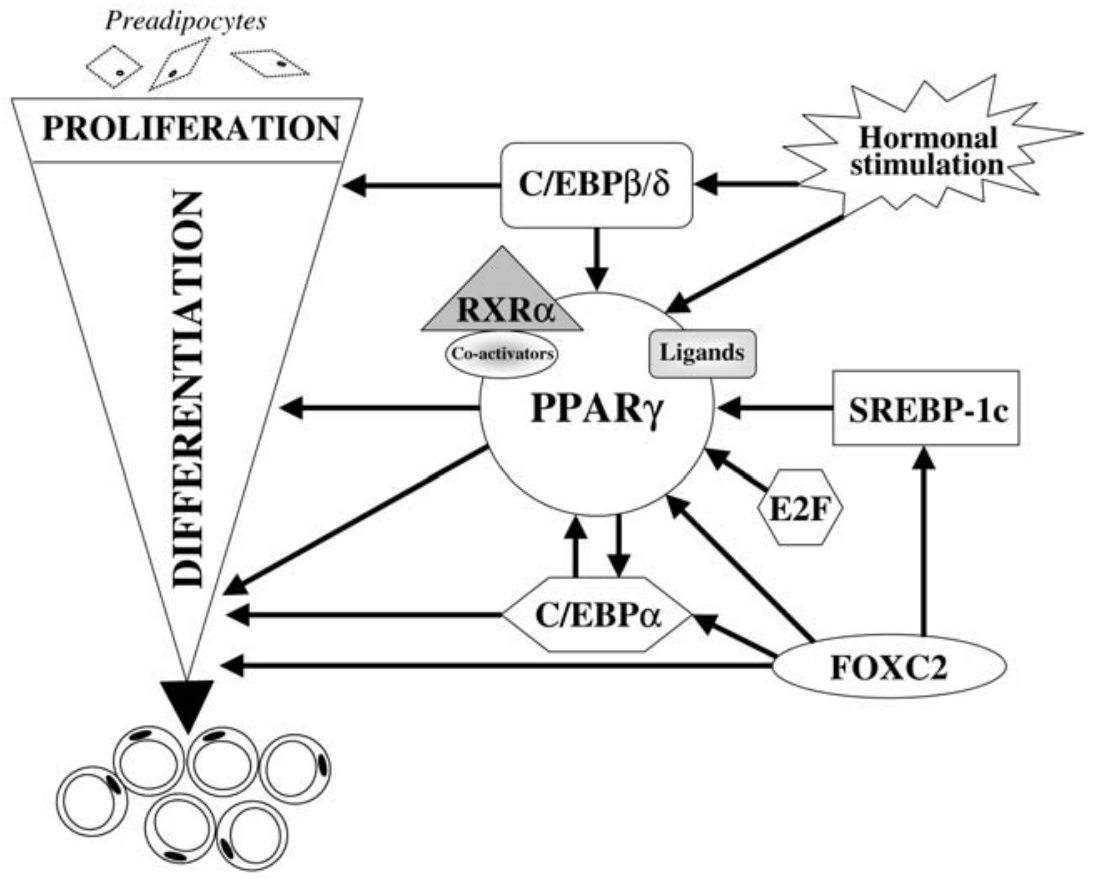

\section{ADIPOCYTE-SPECIFIC GENE EXPRESSION}

Fig. 1. Transcriptional regulation of proliferation and differentiation of adipocytes

PPAR $\beta^{-1-}$ mice is due to a loss of its expression in cell types different to adipocytes as the selective depletion of PPAR $\beta$ in WAT did not yield different phenotypes between transgenic and wild-type rodents [11]. The homozygous deletion of PPAR $\gamma$ is not compatible with life as the protein is essential for placental and cardiac development, in addition to adipocyte differentiation $[10,123]$. PPAR $\gamma^{+/-}$, however, are resistant to adipocyte hypertrophy and insulin resistance associated to a high-fat diet supporting a direct modulatory effect of PPAR $\gamma$ in adipocyte development in response to dietary stimulation [115].

PPARs bind as heterodimers with retinoid $X$ receptor (RXR). Upon binding an agonist, the PPAR conformation is changed and stabilised creating a binding cleft that enables recruitment of transcriptional factors leading to an increase in gene transcription. $\mathrm{RXR} \alpha$ is expressed at high levels in WAT and its deletion is accompanied by in utero mortality [9]. Specific adipose tissue ablation of RXR $\alpha$ yielded mice that do not develop obesity under a high-fat diet and have an impaired increase in plasma NEFA during fasting. These findings provide evidence that RXR $\alpha$ plays a role in both fat accumulation and mobilization [10].

Markedly reduced subcutaneous and visceral WAT with simultaneous enlargement of the interescapular fat depot is observed in overexpression of SREBP-1c. These mice show a normal size at 6 weeks of age while shortly after birth they are smaller than wild type littermates [9]. Accompanying features of these rodents are insulin resistance, hypertriglyceridaemia, lipid-laden internal organs, difficulty in thriving and early death [67]. SREBP-1c has been shown to stimulate both lipogenesis and adipogenesis in cellular models. Absence of SREBP-1 ameliorates fatty livers, but not obesity or insulin resistance in $o b / o b$ mice [110].

Tubby-like proteins. The protein encoded by the tubby gene is a member of the tubby-like proteins gene family [10]. Structure-based functional analysis has showed the participation of these proteins as transcription factors and in $\mathrm{G}$ protein signalling. The absence of the protein encoded by the tubby gene results in an increased body weight accompanied by normoglycaemia, hyperinsulinaemia and hyperleptinaemia together with retinal and cochlear degeneration $[10,25]$. Homozygous mice for the mutation are fertile with the possibility of producing litter before the onset of obesity, which happens around 3 to 4 months in male mice and 4 to 6 months of age in female mice [10].

Other factors promoting adipocyte differentiation. Consistent with a role in development, high mobility group protein I-c (HmgI-c) is only expressed during embryonic and fetal stages. Ubiquitous expression of a truncated Hmgic leads to an increased development of WAT early in life while disruption of one or both alleles of the gene confers resistance to obesity [81]. In addition, lack of Hmgic expression in leptin-deficient mice results in decreased fat pads due to hypoplasia with no evident effect on adipocyte gene expression. Thus, Hmgic seems to play a role in adipocyte precursor proliferation and commitment [11,81].

Forkhead box $\mathrm{C} 2$ (Foxc2) is a winged helix gene expressed in differentiated adipocytes that counteracts 
obesity, hypertriglyceridaemia, and diet-induced insulin resistance [77]. The relevance of this transcription factor becomes evident as mice lacking Foxc2 die during the embryonic or perinatal period. Transgenic mice with selective overexpression in adipose tissue have a lean phenotype with a decreased intraabdominal WAT depot [11]. Adipocytes showed features of brown fat cells with a diminished size, multilocular lipid droplets, and increased number of mitochondria resulting in an augmented thermogenic capacity. Changes in expression of genes with a role in energy dissipation such as PGC-1 and UCP1 has been observed. Moreover, C/EBP $\alpha$, PPAR $\gamma$ and SREBP-1c, genes closely related to adipogenesis, were also increased [77]. Thus, Foxc 2 seems to be involved in the maintenance of the adipocyte phenotype in addition to protecting against overweight and diet-induced insulin resistance.

Information concerning the role of the cell cycle regulator E2F family members has shown that E2F1-3 play a role in the induction of cellular proliferation while E2F4 and 5 appear to be particularly relevant for the transition from cell proliferation to differentiation [106]. The E2F family has been reported to induce PPAR $\gamma$ transcription during clonal expansion (through E2F1) while repressing PPAR $\gamma$ expression during terminal adipocyte differentiation (through E2F4) [106]. Thus, E2Fs play a key role in coordinating the transition between cell proliferation and terminal differentiation because the different proteins of the family have opposing effects on the regulation of PPAR $\gamma$ expression.

\section{Endocrine control}

Insulin signalling. Transgenic and knockout mice have helped to untangle the complex participation of insulin signalling in body weight control. Targeted disruption of the insulin receptor (IR) gene leads to diabetic ketoacidosis and profound postnatal growth retardation followed by neonatal lethality probably in relation to the pleiotropic effects of $I R$ activation [124]. IR null mice have a markedly decreased amount of fat characterised by a reduction of fat cell volume rather than due to a diminished fat cell number [11]. Unlike in mice, patients with leprechaunism, in which the $I R$ is mutant or missing, suffer only from relatively mild hyperglycaemia [124]. IRS $-1^{-1-}$ mice do not show diabetes although they develop beta-cell hyperplasia together with mild insulin resistance attributable mainly to skeletal muscle. In contrast, IRS-2 $2^{-/}$mice show an increased food intake leading to obesity and develop overt early-onset diabetes due to frank hepatic insulin resistance and absent pancreatic compensation [36, 37, 124]. Simultaneous disruption of IRS-1 and IRS-2 by intercrossing renders mice with cells that are completely unable to differentiate into adipocytes [11].
The lethal phenotype of IR inactivation led researchers to focus on tissue-specific elimination of IR in peripheral organs. Muscle-specific insulin receptor knockout (MIRKO) mice do not show apparent disturbances in glucose homeostasis as evidenced by normal glucose and insulin concentrations [42]. However, the mutant mice have increased serum triglycerides and NEFA together with increased visceral fat mass. Although MIRKO mice have a decreased insulinstimulated muscle glucose uptake in vitro and during clamp studies, they achieve a near normal skeletal muscle glucose uptake during a glucose tolerance test $[42,124]$. However, an impaired insulin activation of muscular glycogen synthase that leads to a diminished glycogen content in the muscles of MIRKO mice has been observed. These observations suggest that although insulin is necessary for muscle glucose storage in the form of glycogen, muscle IR signalling is not needed to maintain post-prandial glucose disposal [124]. Selective pancreatic beta-cell insulin receptor knockout $(\beta I R K O)$ mice results in diabetic and obese mice with decreased pancreatic islet size and insulin content as well as loss of glucose-induced first-phase insulin release and age-dependent glucose intolerance [125]. Surprisingly, $\beta$ IRKO-MIRKO mice have a phenotype in which only a mild glucose intolerance is apparent [126]. Mice with tissue-specific disruption of the $I R$ gene in neurons (NIRKO) have an increased food intake leading to diet-induced obesity and insulin resistance [45]. This animal model further supports a role for insulin in the CNS control of body weight by providing a negative feedback loop for post-prandial inhibition of food consumption. NIRKO mice also show an impaired reproduction attributable to dysregulation of pituitary luteinizing hormone secretion, leading to altered ovarian follicle maturation in female mice and perturbed spermatogenesis in male mice [45, 124]. These findings provide additional evidence of the connection between central insulin action, energy allocation and reproductive performance. Liver-specific insulin receptor knockout (LIRKO) mice show fasting hyperglycaemia and severe insulin resistance probably secondary to increased hepatic glucose production rather than to a decreased muscle glucose uptake [127]. The physiological role of insulin signalling in WAT and BAT has been investigated by creating a fat-specific insulin receptor knockout (FIRKO) animal model [76]. Adipocyte-specific inactivation of the $I R$ gene resulted in almost complete protection against age-induced and hyperphagia-induced obesity and the impaired glucose tolerance associated to these conditions [76]. FIRKO mice have a lower body weight due to a reduced fat mass with a disruption of the plasma leptin to adipose mass relation together with a normal insulin sensitivity and glucose homeostasis. Abrogation of the IR in BAT only (BATIRKO) results in agedependent impaired glucose tolerance without insulin resistance [128]. These observations suggest that the 
knockout of the IR in WAT overcomes the detrimental effects on glucose metabolism following lack of insulin signalling in BAT $[127,128]$. Tissue-specific disruption of the $I R$ gene has provided a powerful approach to dissect the direct and indirect effects of the complex insulin signalling pathways showing that insulin is an essential regulator of intermediary metabolism producing a broad spectrum of actions in almost all organs.

Fetuin inhibits insulin-induced IR autophosphorylation and tyrosine kinase activity. Consistent with the participation of the fetuin gene (AHSG) in the susceptibility to develop Type 2 diabetes and the metabolic syndrome, fetuin knockout mice show an improved insulin sensitivity and resistance to weight gain with a decreased body fat when challenged with a high-fat diet [129]. These findings suggest that fetuin plays a role in postprandial glucose disposal, insulin sensitivity, weight gain and fat accumulation.

Insulin-like growth factor. The IGF system, encompassing ligands (IGF-I, IGF-II), receptors (IGF-1R, IGF-2R) and binding proteins (IGFBP) plays a key role during both intrauterine and postnatal development [11]. Mice lacking the $I G F$ genes weigh approximately $60 \%$ less than wild type littermates due to intrauterine growth retardation. Although IGF1-R null pups suffer from reduced weight associated to postnatal birth, the IGF2-R $R^{-l-}$ phenotype shows a fetal overgrowth syndrome leading to death.

Carboxypeptidase. E The fat mutation was originally identified in obese mice and mapped to chromosome 8 [25]. Based on chromosomal localization and on the observation that mice with this recessive mutation have an increase in pancreatic proinsulin lead to the identification of a point mutation in carboxypeptidase E (CPE) being responsible for the phenotype of fat mice [26]. Mutant animals are fertile before the onset of obesity, which becomes evident at about 8 weeks of age [10].

Growth hormone. A rodent genetic model of GH deficiency, the little mouse, shows the participation of GH in somatic growth and body composition [38]. These mice show at the same time a dramatic decrease in body weight and skeletal muscle development as well as a marked increase in adiposity. The changes in body composition take place in the context of an unchanged food intake relative to body weight [10]. The hypothalamic GHS-R regulates GH secretion, feeding, and adiposity [78]. The partial knockout of GHS-R renders rodents with lower body weight and less adipose tissue together with a reduced daily food intake. On the contrary, GH overexpression in rats results in animals with increased amounts of abdominal fat [11]. The unexpected outcome of increased percentage of body fat in the presence of increased GH concentra- tions show the potential opposite effects of short-term and long-term stimulation of the hormone on adipocytes. Furthermore, the continuous secretion of GH by transgenic mice has inhibited the physiological pulsatility and secretory pattern of the hormone resulting in decreased overall mean plasma $\mathrm{GH}$ concentrations [130]. The transgenic rodents developed severe obesity accompanied by increased blood concentrations of glucose, insulin, triglycerides and NEFA. Despite an evident hyperleptinaemia a defective leptin transport from peripheral blood to the cerebrospinal fluid explains that the mutants show an increased food intake $[11,130]$.

Glucocorticoids. Energy balance and appetite are under the control of the hypothalamic-pituitary-axis, which regulates, among others, glucocorticoid production. To dissect the central and peripheral effects of glucocorticoid receptors (GR) the selective inactivation of the $G R$ gene in the nervous system has been studied [80]. A marked growth retardation already from the suckling period was observed with specific reduction in lean body mass accompanied by an increased body-fat content until weaning, followed by a reduced fat accumulation after weaning. These mutant mice are smaller and leaner than their littermates due to decreased food intake and diminished metabolic efficiency. The increased plasma glucocorticoids and hypothalamic $\mathrm{CRH}$ showed by the selective CNS knockout of the GR gene could function as catabolic signals probably leading to a reduced energy accumulation [80]. The relevance of glucocorticoids in the periphery has been addressed by means of other transgenic animal models. It has been shown that $11 \beta$ HSD-1 plays a key role in glucocorticoid reactivation in visceral adipose tissue in obesity $[131,132]$. Evidence for this action is further provided by transgenic mice overexpressing $11 \beta$ HSD-1 in adipose tissue, which have an increased adipose level of corticosterone, hyperlipidaemia, insulin resistance, hyperphagia despite hyperleptinaemia and visceral obesity [15]. These findings strongly support a key role for local production of active glucocorticoids in the development of visceral obesity.

Estrogens. Two complementary gene knockout models have addressed the contribution of estrogens in body weight regulation [20, 62]. Development of ER- $\alpha$ knockout $(\alpha$ ERKO) mice showed that ER- $\alpha$ absence results in marked increases in WAT, but not BAT, insulin resistance and impaired glucose tolerance in both sexes with an added effect of reduced energy expenditure in male mice [62]. Estrogen deficiency can be further attained by targeted disruption of the aromatase gene since this enzyme catalyses the final step in the biosynthesis of $\mathrm{C}_{18}$ estrogens. Aromatase-knockout mice progressively accumulate in- 
creased intra-abdominal adipose tissue [20]. The increased adiposity was not due to hyperphagia or reduced resting energy expenditure, but was associated with diminished spontaneous physical activity, decreased glucose oxidation and reduced lean body mass.

Prolactin. Indirect roles for lactogenic hormones in adipose tissue growth and metabolism has received less attention considering the extremely low expression of prolactin receptors in WAT under physiological circumstances other than pregnancy and lactation. Transgenic mice overexpressing the prolactin receptor show a reduced retroperitoneal fat pad, while no changes in parametrial depots were observed [133]. Prolactin-receptor null mice show a mild reduction in body weight mainly in females and a marked decrease in abdominal fat mass [134].

\section{Gastrointestinal factors}

Endocrine cells scattered throughout the epithelium of the stomach and small intestine secrete numerous peptides that can be released to act locally in the periphery in a paracrine manner, secreted into the bloodstream to act in an endocrine fashion, or released in the brain to act centrally. Cholecystokinin (CCK), glucagon-like peptide-1 (GLP-1), and glucose-dependent insulinotropic peptide (GIP), among others, all known to exert an effect on energy homeostasis at a central and peripheral level have been implicated as putative satiety signals [135]. More recently the involvement of both leptin and ghrelin as gut-derived peptides is being studied [136, 137, 138].

Cholecystokinin. The application of transgenesis to the study of CCK action has yielded the CCK gene knockout as well as the models comprising the deletion of either the CCK-A or CCK-B receptor [10]. Despite the well-established effect on satiety of CCK all three knockout models show normal mature weights further supporting the existence of a highly redundant system warranting energy homeostasis pathways. Transgenic overexpression of pancreatic polypeptide is accompanied by a $50 \%$ postnatal lethality due to decreased milk intake with the surviving mice showing a reduced weight gain and fat mass attributable to a decreased food intake together with a slower gastric emptying rate of solid meals [93].

Bombesin. Mice lacking bombesin receptor subtype-3 $\left(B R S-3^{--}\right)$develop an obesity syndrome, with a $50 \%$ increase in adipose mass as well as concomitant fasting hyperglycaemia and hyperinsulinaemia [9, 23]. $B R S-3^{-/}$further showed a diminished energy expenditure together with a decreased ability to maintain core body temperature upon cold exposure.
Glucose-dependent insulinotropic peptide. Genes that promote the efficient storage of ingested energy in the form of body fat for use during periods of food scarcity are a common feature in evolution-based selection. In this sense, GIP has been recently shown to directly link overnutrition to obesity [107, 139]. Wild-type mice fed a high-fat diet show hypersecretion of GIP, which increases nutrient uptake and triglyceride accumulation in adipocytes leading to extreme visceral and subcutaneous adiposity accompanied by insulin resistance, whereas mice lacking the receptor $\left(\mathrm{Gipr}^{-1-}\right)$ showed a protection against all the mentioned detrimental effects. This protection is attained with a normal oxygen consumption and a reduced respiratory quotient indicating that in $\mathrm{Gipr}^{-/-}$mice fat is used as the preferred energy substrate and, therefore, cannot be effectively accumulated in adipocytes [107]. Crossbreeding of $\mathrm{Gipr}^{-1-}$ with $\mathrm{ob} / \mathrm{ob}$ mice generated a double homozygous model $\left(\mathrm{Gipr}^{-/}, \mathrm{Lep}^{o b} / \mathrm{Lep}^{\mathrm{ob}}\right)$ with a reduced body weight and fat content compared to $o b / o b$ mice, thus confirming that GIP signalling through its receptor takes place in the absence of leptin [107].

Glucagon-like peptide-1. The hormonal factors participating in transmission of signals from the gut to pancreatic beta cells were originally referred to as incretins. GIP and GLP-1 were initially identified as candidate incretins and were thought to be crucial in glucose homeostasis by immediately promoting insulin secretion in response to meal ingestion. Analogously to $\mathrm{Gipr}^{-1-}$ mice rodents lacking the GLP-1 receptor $\left(G L P-1 R^{-/}\right)$show glucose intolerance after glucose loading [108]. While high-fat feeding does not alter glucose tolerance in $G L P-1 R^{-1-}$ mice, glucose homeostasis in GIP receptor-deficient rodents is altered [140]. Furthermore, GLP-1 $R^{-1-}$ mice show a resistance to diet-induced obesity in females, but not in males [108]. These findings suggest that although GIP and GLP-1 act as incretins and belong to the same gastrointestinal family, their physiological roles are not superimposable.

Ghrelin. Ghrelin was first characterised as the natural ligand of the growth hormone $(\mathrm{GH})$ secretagogue receptor, which is expressed by the somatotrophs of the anterior pituitary gland and by neurons in the arcuate nucleus in the basal hypothalamus [137]. The greatest amount of ghrelin-immunoreactivity has been found in neuroendocrine cells of the gastric fundus. In accordance with this localisation ghrelin has been shown to participate in the complex entero-hypothalamic control of food intake signalling. Central or peripheral administration of ghrelin to rodents has been reported to increase food intake and body weight in addition to stimulating gastric motility and acid secretion [138]. The orexigenic effect of ghrelin seems to be mediated partly through activation of NPY/AGRP neurons in 
the arcuate nucleus followed by the increased expression of NPY and AGRP expression in the hypothalamus [138].

\section{Signal transduction}

Obvious targets for unravelling the potential factors participating in body weight regulation include the study of genes involved in signal transduction control. Adenylate cyclase represents one of the principal elements in transmembrane signalling with regard to energy balance since adenylate cyclase (AC) activity determines the levels of intracellular cAMP, which in turn are crucial for lipolysis stimulation. Known modulators of the activity of AC are adrenergic receptors (AR), GTP-binding proteins, protein kinase $\mathrm{A}$ and phosphatidylinositol 3-kinase, among others.

Adrenergic signalling. Of the nine different AR identified to date four, $\alpha_{2}$ and $\beta_{1-3}$, are known to be expressed in adipocytes regulating WAT and BAT development and metabolism through the use of opposite transduction pathways $[11,141]$. In response to a high-fat diet transgenic mice overexpressing the human $\beta_{1}$-AR in WAT have a reduced weight gain and adipose tissue accumulation than their control littermates with brown adipocytes scattered throughout subcutaneous WAT [119]. These findings support the participation of $\beta_{1}$-AR in lipolysis stimulation as well as in increased energy expenditure through heat production. The $\beta_{3}$-AR has been postulated to be the major regulator of adrenergic responses in spite of its lower affinity for endogenous catecholamines [141]. Administration of $\beta_{3}-\mathrm{AR}$ agonists is followed by an increase in metabolic rate, a decrease in food intake with reduction of fat stores in obese rodents [10]. Surprisingly, mice lacking $\beta_{3}$-AR have normal body weight and food intake compared to wild type animals though an increase in total body fat can be observed [63]. Moreover, when challenged with a high-fat diet $\beta_{3}$-AR knockout mice show only a modest tendency towards obesity. These findings suggest that compensatory mechanisms take place in $\beta_{3}-A R^{-/-}$mice to maintain energy homeostasis as evidenced by an upregulation of $\beta_{1}$-AR expression in the WAT and BAT of these mice [10]. The $\beta_{3}-A R^{-/}$mice line has been further used to produce transgenic rodents that express the $\beta_{3}$-AR exclusively in WAT or BAT or both [10, 11]. The majority of effects attributable to $\beta_{3}$-AR activation, such as increased insulin sensitivity and decreased food intake, requires expression of the receptors in WAT, whereas the effect on augmented oxygen consumption depends on $\beta_{3}$-AR expression in BAT. Altogether, $\beta_{3}$-AR in adipose tissue participates in short-term regulation of energy expenditure while its role in the long-term control can be overtaken by other compensatory mechanisms.
It has been recently reported that $\beta$-less mice, i.e. animals lacking all three $\beta-A R$, fed on a standard chow diet have a reduced metabolic rate and become slightly obese but when challenged with a high-fat diet they develop massive obesity attributable to a failure in activating diet-induced thermogenesis [142]. These findings provide evidence that $\beta$-AR are necessary for diet-induced thermogenesis and that the absence of a single $\beta$-AR subtype can be compensated by the remaining AR. In addition, $\beta$-less mice are intolerant to cold exposure suggesting that the sympathetic nervous system and the $\beta$-AR signalling pathways overlap in heat production regulation in response to cold and diet.

A large body of evidence shows that rodents and humans are not comparable in their adrenergic responses based on different receptor tissue distribution, relative AR subtypes ratios and expression levels [11, 141]. While rodents present high levels of $\beta_{3}$-AR and very low expression of $\alpha_{2}$-AR in WAT, in humans $\beta_{3}$-AR mRNA is expressed only in the scarce brown adipocytes with little or no expression in WAT. Thus, although $\beta_{3}$-AR agonists have been described as effective anti-obesity drugs in rodents, their potential application for treating human obesity remains questionable. In addition, in humans the $\beta$-adrenergic response in WAT can be completely counteracted by the $\alpha_{2}$-adrenergic pathway [11]. In fact, the $\alpha_{2} / \beta$-AR ratio in fat depots has been shown to determine the lipolytic rate and to be closely associated with adipose tissue enlargement in obese people [141]. To establish the relative importance of the different AR distribution in humans and rodents a transgenic model mimicking the human characteristics was obtained by targeted expression of human $\alpha_{2}$-AR in the adipose tissue of $\beta_{3}$-AR knockouts [143]. These "humanised" mice developed high-fat diet-induced obesity associated to adipocyte hyperplasia without signs of insulin resistance. Since transgenic mice expressing $\alpha_{2^{-}}$and $\beta_{3}$-AR did not become obese in response to a high-fat diet it can be concluded that obesity requires the presence of $\alpha_{2}$-AR and the lack of $\beta_{3}$-AR in the context of a dietary challenge such as a high-fat diet [11].

$G$ proteins. Heterotrimeric GTP-binding proteins are key elements in transmembrane signalling due to their ability to be coupled with several different receptors. Expression of regulatory $G$ proteins is essential for both catecholamine and insulin signalling in adipocytes. The stimulatory and inhibitory G protein alphasubunits (Gs $\alpha$ and Gi $\alpha$ ) are able to stimulate and inhibit AC activity, respectively. Albright hereditary osteodystrophy, an autosomal dominant syndrome that includes short stature and obesity, is associated with mutations in Gs $\alpha$ [10]. Mice with a homozygous disruption of the ubiquitously expressed Gs $\alpha$ gene are not viable due to embryonic lethality, whereas heterozygotes have different phenotypes depending on the 
parental inheritance of the allele [144, 145]. Mice inheriting the Gs $\alpha$-null allele from the mother $(\mathrm{m}-/+)$ become obese in the early adulthood whereas those with a Gs $\alpha$-null allele derived from the father $(+/ p-)$ are leaner than the control mice. Differences in body weight are not attributable to changes in food intake. Tissue-and sex-specific imprinting of the Gs $\alpha$ gene has been observed with low expression of Gs $\alpha$ in WAT and BAT of $m-/+$ mice leading to an increase in both fat depots while $+/ p$ - animals show a substantial decrease in epididymal WAT and interscapular BAT as a consequence of reduced lipid accumulation in both tissues. Analogously, the effects on energy homeostasis are also characterised by a parental inheritance; whereas $m-/+$ mice are hypometabolic and have a decreased locomotor activity, $+/ p-$ animals are hypermetabolic and more active. The underlying mechanisms for these phenotypes could depend on a decreased Gs $\alpha$-induced lipolysis and thermogenesis stimulation in $\mathrm{m}-/+$ genitors and an increased total sympathetic activity in $+/ p-$ mice $[10,11]$.

The lack of Gi $\alpha$ signalling does not affect body weight but has been reported to participate in insulin action [146]. Because the induction of $\mathrm{Gi \alpha}_{2}$-specific antisense RNA in vivo inhibits neonatal growth, a strategy was designed in which the transgene becomes active at birth [11]. These transgenic mice develop Type 2 diabetes with hyperinsulinaemia, impaired glucose tolerance and insulin resistance. Targeted expression of $\mathrm{Gi \alpha}_{2}$ in fat and muscle further supported the notion that $\mathrm{Gi}$ mimics insulin action unravelling that $\mathrm{Gi \alpha}_{2}$ enhances insulin signalling via suppression of protein-tyrosine phosphatase 1B (PTP-1B) [147]. In turn, mice lacking the $P T P-1 B$ gene show resistance to obesity and an increased insulin sensitivity even on a high-fat diet [116]. Intercrossing of PTP-1B $B^{-/-}$ rodents with leptin-deficient mice also conferred resistance to obesity with an attenuated weight gain and decreased adipose tissue mass in relation with an increased resting metabolic rate [117]. Induction of Goq-specific antisense RNA resulted in increased body mass and adiposity due to a reduced lipolytic response [148].

Protein kinase. A In mice protein kinase A, a ubiquitously expressed cAMP-dependent kinase, is formed by four different regulatory and two catalytic subunit genes that are expressed in a tissue-specific pattern [10]. The RII $\beta$ subunit is abundant in WAT, BAT and certain brain regions and its targeted disruption yields normal-weight mice with approximately $50 \%$ less WAT mass [94]. RII $\beta$-null mice show a slight hyperphagia with normal plasma concentrations of glucose, insulin and lipids and are resistant to a high-fat diet challenge. The lean phenotype is achieved at the expense of an increased lipolytic activity, metabolic rate and body temperature resulting from a compensatory rise in the RI $\alpha$ subunit in WAT and BAT, which is as- sociated with an increased expression of UCP1 [11]. A direct central effect of protein kinase A RII $\beta$ on energy homeostasis should not be completely discarded. RI $\alpha$-null mice suffer early in utero lethality due to severe developmental alterations thus demonstrating the participation of the RI $\alpha$ subunit in cAMP-activated cellular responses essential for life [11].

JAK-STAT signalling. Class I cytokine receptors are known to act through Janus kinases (JAK) and signal transducers and activators of transcription (STAT). JAK proteins are associated with membrane-proximal sequences of the receptor intracellular domain, which is phosphorylated upon ligand binding. The phosphorylated intracellular domain then provides a binding site for a STAT protein, which is activated, translocates to the nucleus and stimulates transcription. Many factors, including erythropoietin, GH, leptin, prolactin and interleukins 2 and 3 (IL-2, IL-3) mediate ligand-induced activation of STAT proteins [4]. Targeted disruption of STAT5a and b has been accomplished to elucidate their contribution in energy balance regulation. All Stat5 mutants showed reduced WAT depots at young ages, with Stat $5 b^{-1-}$ mice developing adult obesity associated with increased epidydimal and abdominal fat amounts [54]. Stat $5 b^{-/-}$male mice show a decreased body growth rate thus providing evidence for the requirement of STAT5b for sexual dimorphism of body growth rates. Consistent with the role of STAT5 in the effects of GH, erythropoietin, prolactin, and a number of hormones and cytokines, all STAT5 mutants presented further alterations such as growth retardation, disrupted haematopoiesis, as well as mammary gland and ovarian development defects [10].

\section{Adipocyte-derived influences}

The adipocyte is no longer considered a passive bystander as fat cells actively secrete a large number of cytokines, adhesion molecules, vasoactive factors, as well as regulators of glucose and lipid metabolism, among other signals, which influence peripheral fuel storage, mobilisation and combustion, as well as energy homeostasis [8, 149].

Leptin. Defective leptin signalling due to either leptin deficiency or dysfunctional leptin receptors leads to early onset severe obesity due to increased adiposity characterised by hyperphagia, decreased energy expenditure, lower body temperature, defective thermogenesis, infertility as a consequence of hypogonadotropic hypogonadism, hyperglycaemia, hyperinsulinaemia, dyslipidaemia, hypothyroidism, and hypercortisolism [3, 4, 5, 6, 7]. Although some of the broad array of metabolic and neuroendocrine alterations such as infertility are normalised in transgenic $o b / o b$ 
mice expressing about $50 \%$ of the physiological leptin concentrations under the control of an adipocyte promoter, the animals continue to show a moderately obese phenotype [150]. Meanwhile, chronic hyperleptinaemia achieved in normal mice by the same transgenic approach yields rodents that accumulate adipose mass at an older, but not younger age [151]. In contrast, transgenic skinny mice overexpressing leptin by an hepatic promoter results in accelerated puberty, high blood pressure, increased glucose metabolism and insulin sensitivity accompanied by complete disappearance of WAT and BAT [97]. The selective deletion of leptin receptors in neurones leads to obesity in a lesser extent than that observed in leptin receptornull mice and only to slight glucose intolerance in some cases suggesting that the peripheral effects of leptin contribute to the full manifestation of the syndrome [47]. To unravel the concrete contribution of leptin in the periphery a similar approach to that carried out with the IR with targeted disruption of the leptin receptor in adipocytes, liver, skeletal muscle, etc. has to be undertaken.

Interleukin-6. IL-6 is considered to be an inflammatory mediator as well as a stress-induced cytokine with pleiotropic effects on a variety of tissues, including stimulation of acute phase protein synthesis, increase in thermogenesis as well as increased activity of the hypothalamic-pituitary axis and down-regulation of adipocyte lipoprotein lipase (LPL) [8]. Although increased concentrations of IL- 6 have been detected in obese subjects, IL-6-deficient mice develop matureonset obesity accompanied by an increased subcutaneous fat mass with the obese phenotype being only partly reversed by IL-6 replacement [35]. Since the lack of this immune-modulating cytokine confers resistance to the decrease in food intake caused by tumour burden or infection it has been suggested that IL-6 plays a role in the regulation of food intake in pathological states [10].

Interleukin-1. IL-1 has also been proposed as a potential mediator of cancer cachexia based on the transgenic mice obtained either lacking or overexpressing the IL-1 receptor antagonist (IL-1ra), the endogenous inhibitor of IL-1 [83]. Consistent with the participation of IL-1 in body weight regulation, $I L-1 \mathrm{ra}^{-/}$ mutants weigh less than wild type control mice. In addition, mice lacking IL-1 $\beta$ converting enzyme, which produces biologically active IL-1 $\beta$, are resistant to the anorectic effects of lipopolysaccharide [10]. Paradoxically, overexpression of IL-1 ra yields mice with similar body weights to those of wild type animals.

Tumour necrosis factor- $\alpha$. TNF- $\alpha$ inhibits the expression of two master regulators of adipose differentiation, CEBP $\alpha$ and PPAR $\gamma 2$ [8]. This suppression could result in the subsequent down-regulation of many adipocyte specific proteins such as LPL, aP2, FAS, ACC, and GLUT4 among others. Furthermore, mature adipocytes are stimulated to mobilise lipids upon TNF- $\alpha$ exposure, possibly via hormone sensitive lipase (HSL) activation. Among the multiple properties of TNF- $\alpha$ the antiadipogenic effect is especially relevant as adipose conversion of fat cell precursors is potently inhibited by TNF- $\alpha$ [8]. Several genetic models lacking different elements of the TNF- $\alpha$ system, such as TNF- $\alpha$-deficient mice and animals lacking the expression of either one or both TNF- $\alpha$ receptor subtypes, have been generated [10]. While one study [96] found that younger mice lacking TNF- $\alpha$ expression tended to weigh less than wild type animals with significant changes becoming evident at older ages, another study [152] reported no difference in body weight of $T N F-\alpha^{-1-}$ on either a standard or a high-fat diet. $T N F$ - $\alpha$-deficient mice showed decreased glucose, insulin and leptin concentrations showing an impaired glucose clearance when challenged with a high-fat diet as evidenced by increased circulating glucose and insulin, which did not reach the concentrations of wild-type control mice [10, 96, 152]. Disruption of TNF- $\alpha$ receptors expression had no effect on body weight or glucose homeostasis when mice were fed on a standard diet [113]. However, on a high-fat diet only mutants lacking the $\mathrm{p} 75$ receptor showed a lower body weight together with decreased leptin concentrations compared to wild types. Absence of both receptor subtypes (p55 and p75) resulted in severe hyperinsulinaemia on a high-fat diet, especially after a short fasting period [113]. The lack of TNF- $\alpha$ receptors has been further studied in leptin-deficient $o b / o b$ mice evidencing that while the absence of $\mathrm{p} 75$ does not affect insulin resistance, the deficiency of p55 improves insulin sensitivity [153]. Thus, TNF- $\alpha$ could play a role in obesity-related insulin resistance though with the participation of other factors in the development of this syndrome. An unexpected role for TNF- $\alpha$ in thermogenesis control in genetic and dietary models of obesity can be inferred from the findings that in obese mice lacking either TNF- $\alpha$ or its receptors an increase in BAT UCP1 and $\beta_{3}$-AR expression are observed in association to a rise in multilocular functional brown adipocytes [154].

Resistin. By screening for genes that were induced during the differentiation of adipocytes but were down-regulated in mature adipocytes exposed to an insulin-sensitizing drug, a new peptide hormone that belongs to a family of tissue-specific resistin-like molecules originally named for its resistance to insulin was identified [155]. Although the seminal proposal suggested resistin to be a hormone that links obesity to diabetes, several subsequent studies support the concept that insulin resistance and obesity are actually associated with a decreased resistin expression [155]. 
The way resistin was measured and the differences between serum concentrations and mRNA and protein levels probably contribute to the inconsistency. A variety of agents and hormones, including thiazolidinediones, insulin, TNF- $\alpha$ and GH have been shown to participate in the regulation of resistin expression. However, in this case too contradictory results have been reported [155]. The apparent inconsistency of current experimental evidence does not rule out the possibility that resistin plays a role in metabolic disorders. In this sense, the generation of the resistin knockout model could prove helpful in establishing the contribution of resistin in the development of obesity and insulin resistance.

Adiponectin. The cDNA encoding adipocyte complement-related protein of $30 \mathrm{kDa}$ (Acrp30), also termed as adiponectin, was isolated by a substractive hybridization screen comparing 3T3-L1 adipocytes with undifferentiated preadipocytes [156]. The Acrp30 mRNA was induced over 100-fold during differentiation and was found to be expressed exclusively in adipocytes. Contrary to what is observed with most adipocyte-derived factors, which in general are proportional to overall adipose mass, circulating adiponectin concentrations are lower in obese than in lean subjects [156]. Adiponectin has been shown to decrease the postprandial rise of plasma NEFA, to improve postabsorptive insulin-mediated suppression of hepatic glucose output with a strong correlation between plasma adiponectin and systemic insulin sensitivity being evident. Furthermore, adiponectin has been shown to have effects on monocyte adhesion to endothelium, myeloid differentiation and macrophage cytokine production and phagocytosis, processes related to atherosclerotic plaque formation [156]. At present, it is not known if the main role of adiponectin is a direct antiatherosclerotic effect or if it exerts its activity through the modulation of lipid metabolism and/or regulation of insulin sensitivity.

Nitric oxide. Inflammatory cytokines produce inducible nitric oxide synthase (iNOS) stimulation in skeletal muscle and WAT, which in the long-term has been proposed to cause insulin resistance in muscle. Increased iNOS expression in myocytes and adipocytes of genetic and dietary models of obesity have been described [157]. Moreover, targeted disruption of iNOS has been shown to protect against dietary-induced insulin resistance in muscle. While both wild type and $i N O S^{-1-}$ mice develop obesity associated to hyperphagia when put on a high-fat diet, the latter show an improved glucose tolerance, normal muscle insulin sensitivity and insulin-stimulated muscular glucose uptake despite the increased body weight and adiposity [157]. Obese $i \mathrm{NOS}^{-/-}$mice remained glucose intolerant as evidenced by increased fasting glycaemia in spite of the improvement in muscle insulin sensitivity, which can be explained by the lack of effect of iNOS disruption in preventing defective hepatic and WAT insulin signalling. Endothelial NOS (eNOS), which is expressed in endothelium and skeletal muscle, is also involved in mediating insulin sensitivity with $\mathrm{eNOS}^{-/-}$ mice showing fasting hyperinsulinaemia, hyperlipidaemia and defective insulin-stimulated glucose uptake besides hypertension [158].

Other vasoactive factors. Compelling evidence about the role played by adipocytes in cardiovascular physiology has been gathered over the last years. An increasing number of products secreted by adipocytes such as angiotensinogen (AGT), plasminogen activator inhibitor-1 (PAI-1), adhesion molecules, tissue factor and transforming growth factor- $\beta$ (TGF- $\beta$ ), promote the consideration of adipose tissue as a source of vasoactive factors. Blood vessels express receptors for most of the adipocyte-derived factors, thus drawing attention to the existence of a network of local and systemic signals. AGT expression is increased in obesity and adipocytes have been shown to be able to secrete AGT itself as well as angiotensin converting enzyme [8]. During fasting a decrease in AGT mRNA above control has been observed, which increases upon refeeding. Furthermore, these changes in gene expression are paralleled by fluctuations in AGT secretion from isolated adipocytes [8]. AGT-deficient mice show impairment of diet-induced weight gain with alteration in adipose tissue development and increased locomotor activity [103]. In contrast, overexpression of AGT in wild type mice produces an increase in body weight due to preadipocyte proliferation and differentiation through FAS gene induction [19].

Among the multiple mechanisms that may explain the relationship between obesity and cardiovascular disease, disorders of the fibrinolytic system are very plausible candidates [8]. In fact, increased plasma concentrations of PAI-1 have been found in obese subjects and a close correlation with an abdominal pattern of adipose tissue distribution in both men and women as well as a positive association with other components of the insulin resistance syndrome have been reported [8]. Insulin, TNF- $\alpha$, IL-1 $\beta$ as well as TGF- $\beta$ have a stimulatory effect on PAI-1 protein secretion and could contribute to the augmented PAI-1 concentrations observed in obesity and insulin resistance. The transgenic approach has contributed with the observation that disruption of the PAI-1 gene reduces the adiposity and improves the metabolic profile of genetically obese and diabetic ob/ob mice [114].

TGF- $\beta$ is a multifunctional cytokine produced by a variety of cells, which is capable of regulating the growth and differentiation of numerous cell types [8]. It has been implicated in a number of biological processes including cell adhesion and migration, extracellular matrix production, tissue remodeling, and wound repair. TGF- $\beta$ mRNA expression has been shown to 
be higher in adipose tissue of $o b / o b$ and $d b / d b$ mice compared to their lean littermates [8]. The increased gene expression of TGF- $\beta$ in adipose tissue could have broad implications in the pathophysiology of obesity and its associated complications since TGF- $\beta$ has been shown to increase preadipocyte cell proliferation, thereby contributing to the increased cellularity of fat depots related with the obese phenotype. Both obesity and Type 2 diabetes are also associated with characteristic long-term complications, including microvascular kidney disease. Intercrossing of $o b / o b$ mice with $T G F-\beta 1$-overexpressing animals reverses the obese phenotype, but results in a lipodystrophylike syndrome accompanied by liver fibrosis, hepatosplenomegaly and glomerulosclerosis [90].

A further class of obesity-related genes encodes leukocyte adhesion molecules as well as their receptors. Mice lacking either leukocyte integrin $\alpha \mathrm{M} \beta 2$ or its receptor, intercellular adhesion molecule-1 (ICAM-1), develop an obese phenotype at an old age when fed a standard chow diet or at a young age when challenged with a high-fat diet [34]. The weight gain takes place due to an increased adiposity predominantly of the subcutaneous depot without an augmented food intake suggesting a defective energy utilization mechanism. ADAM, a disintegrin and metalloproteinase protein family member involved in the cleavage of membrane anchored precursor of TNF- $\alpha$, has been also shown to participate in adipose mass control. Overexpression of ADAM 12 protease reportedly induces adipogenesis leading to increased body weight and adiposity in female mice and slight overweight in male mice [17], whereas disruption of the gene encoding ADAMTS-1, a metalloproteinasedisintegrin essential for normal growth, fertility, and organ morphology and function, result in growth retardation and adipose tissue malformation [159].

Metallothioneins (MT) comprise a family of highly conserved metal binding proteins that have been proposed to participate in metal homeostasis through zinc and copper detoxification by scavenging free radicals with a potential involvement in oxidative stress protection $[10,11]$. In addition to suffering an increased sensitivity to the toxic effects of metals, mice lacking the ubiquitously expressed MT-I and MT-II became heavier than the controls at about 5 weeks of age [43]. Hyperphagia and obesity were accompanied by a substantially increased epididymal fat depot as well as by hyperinsulinaemia and hyperleptinaemia in MT-I and -II null mice [43]. The underlying mechanisms linking obesity to the absence of MT expression have not been fully elucidated though increased fat accretion associated with increased LPL and $\mathrm{C} / \mathrm{EBP} \alpha \mathrm{mRNA}$ expression have been reported.

\section{Transport molecules and enzymes governing glucose and lipid metabolism}

The role in energy balance control of numerous elements participating in intermediary metabolism has been shown through a large number of transgenic and knockout mouse models. Transport molecules and enzymes are step-limiting regulators of certain reactions controlling glucose and lipid metabolism as well as thermogenesis, which have been proven to exert a direct influence on body weight control.

Uncoupling proteins. UCP1 plays a decisive role in thermoregulation and in protecting against dietinduced obesity in rodents by uncoupling oxidation of fuels from ATP production in BAT mitochondria, resulting in heat generation instead. Genetic ablation of BAT leads to obesity and an increase in total body lipid owing to hyperphagia, lower core body temperature and decreased metabolic rate [57]. In addition, transgenic mice are hyperglycaemic, hyperinsulinaemic and hyperleptinaemic with a normoresponsive HPA axis as evidenced by normal somatic growth and fertility. Unexpectedly, Ucpl knockout mice do not develop hyperphagia and obesity but are sensitive to cold [160], thus providing evidence for the existence of additional BAT-derived factors responsible for diet-induced thermogenesis. Ucpl-deficient mice have a normal resting metabolic rate but have a blunted $\beta$-adrenergic stimulated oxygen consumption. Sensitivity to cold depended on the genetic background of the animals. While in the initial study $85 \%$ of the mice with a mixed 129/SvPas and C57BL/6J background were sensitive to cold, animals on a $129 / \mathrm{SvPas} \mathrm{x}$ C57BL/6J F1 hybrid background were resistant to cold despite the absence of $U c p l$. The difference in cold-sensitivity between the diverse mouse lines is not attributable to compensation by the other UCPs, but represents an example of hybrid vigour or heterosis. The phenotypic discrepancies regarding obesity between mice lacking BAT and Ucpl knockouts suggests the existence of a BAT-brain signalling system involving the potential secretion of a centrally acting factor. Constitutive expression of Ucpl in WAT and BAT confers resistance to both genetic-related and diet-induced obesity with a special reduction of the subcutaneous fat depots $[68,99,161]$. Transgenic expression of Ucpl in skeletal muscle also prevents diet-induced obesity due to an increased resting metabolic rate, and insulin resistance as a consequence of augmented respiratory uncoupling [100]. On the contrary, ectopic overexpression of Ucp3 provides resistance to obesity despite hyperphagia [98]. Targeted disruptions of $U c p 2$ or $U c p 3$ do not affect adipose tissue development or cold responsiveness [11]. The lack of evident alterations in body weight in all three knockout models is probably related to compensatory mechanisms. 


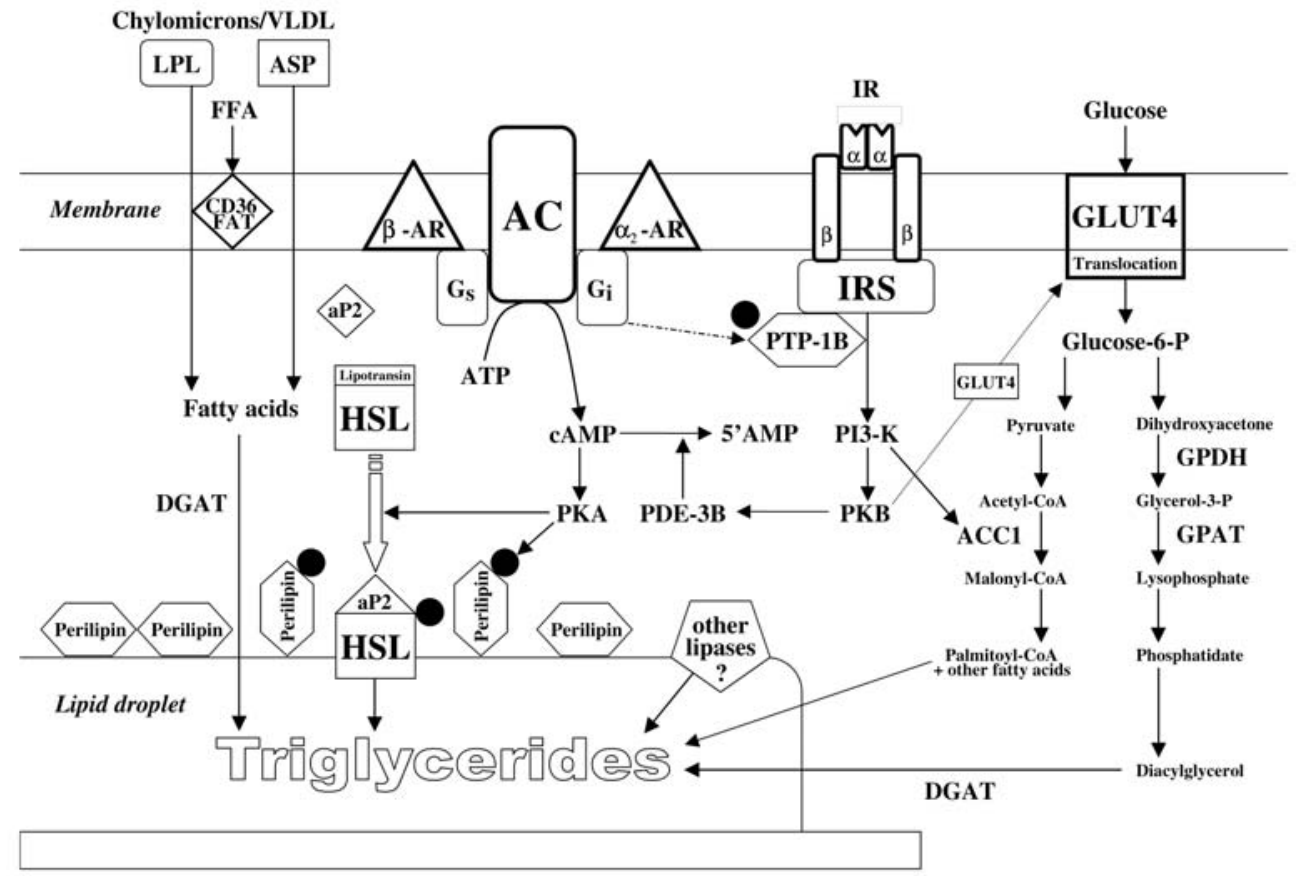

Fig. 2. Schematic representation of the main triglyceride metabolism pathways in adipocytes

Eukaryotic translation initiation factor. An increased thermogenesis has also been observed in relation to the inactivation of the eukaryotic translation initiation factor 4E-binding protein 1 (eIF4E-BP1) leading to smaller WAT pads and an increased metabolic rate in Eif4ebp $1^{-1-}$ mice [75]. Of interest, the decreased adiposity is accompanied by a shift in the characteristic features of white adipocytes to those of brown fat cells as evidenced by a multilocular aspect and a marked increase in UCP1 mRNA expression owing to an increased PGC-1 translation in WAT, thus unravelling a new molecular mechanism of energy expenditure control at the translational level [75].

Glucose metabolism. The glucose transporter 4 (GLUT4) is primarily expressed in tissues responding to insulin-stimulated glucose uptake such as WAT, BAT, skeletal and cardiac muscle [10]. Two transgenic models overexpressing GLUT4 specifically in adipose tissue [32] or in fast-twitch skeletal muscle [162] have been generated. GLUT4-null mice have also been produced [79, 163] and intercrossed with the animals overexpressing GLUT4 in skeletal muscle fibres to yield a line that expresses GLUT4 only in fast-twitch muscles [162]. Increased body weight and total lipid content due to adipose cell hyperplasia together with an enhanced glucose disposal were observed in transgenic mice overexpressing GLUT4 selectively in adipose tissue [32]. Overexpression of GLUT4 specifically in fast-twitch muscles did not affect body weight but lead to decreased fasting glycaemia and an increase in insulin-stimulated glucose clearance [162]. GLUT4 ${ }^{-1-}$ mice are characterised by a decreased body weight due to a marked WAT reduction accompanied by normoglycaemia and a normal response to a glucose load [79]. However, mice deficient in GLUT4 show increased postprandial glycaemia together with a diminished insulin sensitivity in an insulin tolerance test [79]. Further evidence for the compensatory mechanisms operating in part in GLUT4 ${ }^{-/-}$mice is provided by GLUT4 heterozygous mutants, which develop diabetes with hyperglycaemia and hyperinsulinaemia 2 months after birth, when GLUT4 expression starts to decline [164]. Muscle-specific transgenic complementation of GLUT4-deficient mice yielded animals with decreased body weight and adiposity showing normoglycaemia and insulinaemia as well as a normal glucose clearance in response to insulin [162]. The degree of glucose intolerance and insulin resistance in GLUT4 ${ }^{-1-}$ mice is similar to that seen in mice with muscle-selective ablation of GLUT4 [163], thereby suggesting distinct and complementary roles of adipose tissue and skeletal muscle in mediating glucose disposal in vivo. Selective inactivation of the GLUT4 gene in adipose tissue had no effect on growth, body weight, fat mass and cardiac development, but impaired insulin action in muscle and liver leading to glucose intolerance and insulin resitance [165]. Thus, glucose transport in adipose tissue plays a critical role in glucose homeostasis. The adipose-selective downregulation of GLUT4 seen in human obesity and Type 2 diabetes mellitus could contribute to insulin resistance and to the risk of developing Type 2 diabetes.

Lipid metabolism. Transgenesis has helped to provide insight into the recognised but partly misunderstood participation of cellular lipid metabolism in energy homeostasis (Fig. 2). Numerous mouse models with 
disruptions in pathways relevant to fatty acid and triglyceride metabolism have been generated. Fatty acids circulate in the bloodstream as nonesterified molecules, bound to albumin, or in the core of lipoproteins. VLDL receptor ${ }^{-1}$ mice are resistant to both genetic and diet-induced obesity caused by a decreased peripheral and whole-body uptake of NEFA with no alteration in either food intake or fat absorption [118]. The reduction in adipocyte triglyceride storage as shown by a decreased average fat cell size in VLDL receptor-deficient rodents implies an impaired fatty acid delivery to adipose tissue in the absence of this lipoprotein receptor [118]. Analogously, hepatic overexpression of human apolipoprotein C-I leads to hyperlipidaemia accompanied by decreased visceral fat depots and lack of subcutaneous WAT in mice [166]. On the contrary, overexpression of apoA-II, the second most abundant HDL component, results in increased adiposity and insulin resistance in relation to a decreased skeletal muscle glucose uptake [167]. In the capillaries of skeletal muscle and adipose tissue, LPL catalyses the rate-limiting step in the hydrolysis of triglycerides from circulating VLDL and chylomicrons. Thus, LPL plays an important role in directing fat partitioning. In fact, LPL deficiency results in minimal amounts of tissue lipids leading to neonatal death due to marked hypoglycaemia and hypertriglyceridaemia [168]. In heterozygotes only mild hypertriglyceridaemia with impaired LDL clearance and mild hyperinsulinaemia accompanied by an approximately $20 \%$ decrease in fasting glucose concentrations was observed. Exclusive LPL deficiency in adipose tissue on a standard genetic background renders a normal growth and body composition. This implies that although LPL controls fatty acid entry into adipose tissue, fat mass is preserved by endogenous synthesis [109]. When the same lack of LPL in adipose tissue is generated on an $o b / o b$ background a diminished weight gain is attained as a consequence of an impaired lipid accumulation in adipocytes. On the contrary, targeted overexpression of LPL in skeletal muscle or liver has no effect on body weight, but produces an increase in fatty acid uptake into the respective tissue adversely affecting glucose metabolism [169].

Acylation-stimulating protein (ASP), an adipocytederived cleavage product of complement $\mathrm{C} 3$, stimulates fatty acid reesterification and glucose transport at the same time as inhibiting HSL and, hence, lipolysis. Since mice lacking complement $\mathrm{C} 3$ are unable to produce ASP, $C 3$ gene knockout rodents are consequently ASP-null animals $[10,11]$. ASP-deficient mice show a reduced WAT weight, distributed evenly through all depots in females while primarily affecting gonadal and perirenal localizations in males [70]. The reduced adipose mass was accompanied by hypoleptinaemia with a modest increase in food intake. When fed on either a low-fat or high-fat diet male $A S P^{-/-}$mice show no differences in body weight compared to wild type animals. Female $A S P^{-1-}$ mice, however, had a decreased body weight compared to their wild type counterparts. The relatively mild phenotype of these mice suggests a minor role of ASP in fat storage and lipolysis control or the existence of compensatory mechanisms rescuing part of the physiological functions of ASP.

The transport of NEFA into cells is facilitated by another fatty acid transporter (FAT), the CD36/FAT molecule, which is expressed in tissues with a high metabolic capacity for fatty acids such as WAT, skeletal muscle and heart $[11,169]$. CD36 is a class B scavenger receptor that binds multiple ligands, including fatty acids, and has been proposed to function as a transporter of long-chain NEFA acting as a gatekeeper. Fat cells of CD36 null mice show a decreased capacity to incorporate long-chain NEFA into triglycerides [170]. Although neither the effects of CD36 deficiency on adipose mass, adipocyte size or insulinaemia have been reported, an approximately $30 \%$ reduction in plasma glucose concentrations has been observed. Transgenic mice overexpressing CD36 in skeletal muscle showed increased glucose and insulin concentrations together with decreased plasma concentrations of NEFA and triglycerides at the same time as having a markedly increased fatty acid oxidation in muscle [87].

Gene targeting has revealed that mice lacking Dgatl are capable of synthesizing triglycerides and reach a normal body weight on a standard chow diet although with an approximately 50\% reduction in fat mass, adipocyte size and leptinaemia [105]. In addition, after a glucose load Dgatl-deficient rodents have a decreased plasma glucose response, consistent with an increased insulin sensitivity that correlates with a diminished muscular and hepatic triglyceride content [169]. Surprisingly, DGAT1 deficiency has no effect on plasma triglycerides and NEFA, probably due to a compensation by DGAT2 or alternative pathways of conversion of diglycerides to triglycerides [171]. Dgat1 ${ }^{-1-}$ mice, however, are resistant to diet-induced obesity, which is related to an increased energy expenditure independent of increased lean body mass or changes in cold-induced thermogenesis.

Malonyl-CoA is a key metabolite generated by ACC1 and ACC2 that plays a pivotal role linking fatty acid and carbohydrate metabolism through fatty acid oxidation and synthesis in response to hormonal and dietary influences. ACC1 is highly expressed in the cytosol of adipocytes and hepatocytes, while ACC2 is localised in the mitochondria being predominantly expressed in skeletal muscle and heart. Deciphering the roles of the carboxylases in energy homeostasis in lipogenic and non-lipogenic tissues has been approached by the generation of $A c c 2^{-/-}$mice [65]. In comparison to wild type controls, mutant mice had a 
$30 \%$ higher fatty oxidation rate and accumulated $50 \%$ less fat in their adipose depots. Mutants, however, had a normal growth rate despite consuming 20 to $30 \%$ more food than the control mice.

Although the fibroblast growth factor (FGF) proteins have been primarily related to fibroblast and epithelial cell proliferation, more recently relevant roles in physiological homeostatic control have been attributed to some of the newly described FGFs. In this context, it is interesting to point out that transgenic mice overexpressing FGF19 show a specific reduction in fat mass resulting from an increased energy expenditure due to an increased BAT mass and a decreased hepatic ACC2 expression [172]. Furthermore, FGF19 transgenic mice do not develop obesity or diabetes on a high-fat diet.

Triacylglycerol stores play a critical role in the ability to withstand fuel deprivation through the release of glycerol and NEFA by lipolysis. The lipid droplets contained in adipocytes are coated by structural proteins, such as perilipin, that stabilise the single fat drops and prevent triglyceride hydrolysis in the basal state. The phosphorylation of perilipin after adrenergic stimulation or other hormonal inputs induces a structural change of the lipid droplet that allows the hydrolysis of triglycerides. The participation of perilipin in body weight regulation has been addressed by knockout approaches from different experimental groups [91, 92]. Perilipin-deficient mice show an increased lean body mass accompanied by an increased metabolic rate together with an increased basal lipolytic rate, which confer resistance to diet-induced obesity. Although absence of perilipin results in leanness and reversal of obesity with an approximately $50 \%$ decrease in adipose mass and adipocyte size, it does not enhance glucose intolerance [91], even with perilipin ablation being able to worsen glucose disposal [92].

HSL has been typically considered the key enzyme catalysing the rate-limiting step of lipolysis. Mice lacking HSL show normal growth rates and body weights [173]. While the epididymal, retroperitoneal and femoral WAT depots of $H S L$-deficient rodents remain unchanged, these mice show a $65 \%$ increase in BAT mass compared to wild type control mice. Although catecholamine-induced lipolysis was markedly blunted, the basal lipolytic activity was unaltered. The findings concerning the lack of obesity and mild adipocyte hypertrophy observed in $H S L$-null mice suggests that other lipases could also play a relevant role in fat mobilisation. The changes observed in triglyceride-rich lipoprotein metabolism have been attributed to a downregulation of hepatic VLDL synthesis and an upregulation of LPL activity in WAT and skeletal muscle [174].

Lipolysis activation could also depend on proteins not directly participating in the catalytic process. Two proteins have been shown to interact with HSL, name- ly adipocyte lipid binding protein (ALBP or aP2) and lipotransin [175]. HSL is not associated with the lipid droplet and is probably tethered to lipotransin, while perilipin coats the lipid droplet and hinders the access of HSL to it. After hormonal stimulation, HSL and perilipin are phosphorylated and HSL translocates to the lipid droplet. ALBP then binds to the N-terminal region of HSL, preventing fatty acid inhibition of the enzyme's hydrolytic activity. Consistently, $a P 2^{-/-}$ mice show an approximately $40 \%$ decreased basal and isoproterenol-stimulated lipolytic rate [176, 177]. These ALBP-deficient rodents show a normal growth rate, body weight and body composition compared to wild type littermates due to a functional compensation by the fatty acid binding protein of keratinocytes [46, 178]. However, when exposed to a high-fat diet $a P 2^{-/-}$ mice develop diet-induced obesity reaching a greater total weight gain than the control mice as a consequence of an increased fat pad weight. Both lean and obese $a \mathrm{P}^{-{ }^{-}}$mutants show normoglycaemia and normoinsulinaemia providing evidence for an uncoupling of obesity from insulin resistance through ALBP deficiency $[46,176]$.

Glycerol 3-phosphate dehydrogenase (GPDH) is a ubiquitously expressed enzyme participating in triglyceride synthesis as well as in shuttling NADH into mitochondria for oxidative metabolism. Transgenic mice overexpressing GPDH show a normal body weight but with an increased interscapular brown fat depot and virtually no WAT [179]. On the contrary, animals lacking mitochondrial GPDH show a decreased body weight compared to wild type mice with no reported effect on adipose tissue depots but a marked insulin release defect when the malate-aspartate shuttle is blocked. This indicates an important role of the NADH shuttle or glycerol phosphate system in glucose-induced activation of mitochondrial metabolism and insulin secretion [88]. Therefore, the two mouse models with altered expression of $G P D H$ provide evidence for an involvement of this enzyme in lipogenesis and WAT development as well as in the regulation of the glycolytic pathway.

The synthesis of triglycerides and glycerophospholipids starts with the acylation of glycerol-3-phosphate by glycerol-3-phosphate acyltransferase (GPAT) to form lysophosphatidic acid. Mammals have two isoforms of the enzyme, located in the outer mitochondrial membrane (mtGPAT) and the endoplasmic reticulum (microsomal GPAT). It has been recently reported that $\mathrm{mtGpat}^{-1-}$ mice have reduced weight and fat pad mass accompanied by lower liver and plasma triacylglycerol, together with a lower VLDL secretion rate and an altered glycerolipid fatty acid composition [180].

During the last decade the generation of transgenic mouse models has begun to provide valuable though fragmented insight into the mechanisms by which cellular lipid metabolism modulate body weight regu- 
lation. Accumulating evidence for important functions of enzymes involved in the anabolic and catabolic processes of lipid metabolism has been obtained through targeted disruption in rodent models of genes controlling triglyceride metabolism. However, direct links between abnormal expression or genetic variations and human disorders such as obesity, hyperlipidaemia, insulin resistance, and Type 2 diabetes await further clarification.

\section{Concluding remarks}

The slow progress in understanding body weight regulation shows the multifactorial and highly intricate adaptive mechanisms developed over time against weight loss. Current evidence for the involvement of several different factors in energy balance regulation indicates that body weight homeostasis and food intake control are far more complex than initially thought from the predictions of a single circulating satiety factor derived from the classic parabiosis studies. The identification of genes that cause obesity, leanness or provide resistance against obesity development have added new pieces to the puzzle of body weight control. In addition, transgenesis has stimulated the impetus for the search of potentially unsuspected physiological consequences of already known gene products. However, it has to be stressed that studying single genes independently through the analysis of genetically modified animal models provides only a fragmented view of what has to be considered - in most cases - a multigenic pathology such as obesity. Thus, it is vital to avoid oversimplified views. In this sense, information derived from traditional physiological studies continues to deliver relevant clues for a better understanding. Trying to integrate findings obtained from both whole-body physiology as well as transgenic experiments represents a useful approach to explore the equilibrium achieved to compensate for fluctuations in body weight. Control of gene expression from a quantitative, qualitative and spatiotemporal perspective together with functional genomics embodied by DNA microarrays will provide new clues to characterise modified and modifier genes that influence transgene-dependent phenotypes. Such complementary approaches could prompt the design of new drugs for the treatment of obesity as well as open up the field of pharmacogenomics.

Sources. This review is based on the relevant literature published in the English language during the period 1990-2002, and seminal prior contributions. The sources available to the authors were integrated with sources identified through PubMed searches for "body weight, obesity, leanness or adipose tissue" combined with searches for "knockout, transgenic or overexpression".
Acknowledgements. The general support of the departamental chairs of Drs. J.A. Cienfuegos and J. Salvador is gratefully acknowleged.

\section{References}

1. Kennedy GC (1953) The role of depot fat in the hypothalamic control of food intake in the rat. Proc R Soc Lond B Biol Sci 140:578-592

2. Coleman DL (1973) Effects of parabiosis of obese with diabetes and normal mice. Diabetologia 9:294-298

3. Zhang Y, Proenca R, Maffei M, Barone M, Leopold L, Friedman JM (1994) Positional cloning of the mouseobese gene and its human homologue. Nature 372:425-432

4. Frühbeck G, Jebb SA, Prentice AM (1998) Leptin: physiology and pathophysiology. Clin Physiol 18:399-419

5. Woods SC, Schwartz MW, Baskin DG, Seeley RJ (2000) Food intake and the regulation of body weight. Annu Rev Psychol 51:255-277

6. Frühbeck G (2001) A heliocentric view of leptin. Proc Nutr Soc 60:301-318

7. Frühbeck G, Gómez-Ambrosi J (2001) Rationale for the existence of additional adipostatic hormones. FASEB J 15:1996-2006

8. Frühbeck G, Gómez-Ambrosi J, Muruzábal FJ, Burrell MA (2001) The adipocyte: a model for integration of endocrine and metabolic signaling in energy metabolism regulation. Am J Physiol 280: E827-E847

9. Inui A (2000) Transgenic study of energy homeostasis equation: implications and confounding influences. FASEB J 14:2158-2170

10. Robinson SW, Dinulescu DM, Cone RD (2000) Genetic models of obesity and energy balance in the mouse. Annu Rev Genet 34:687-745

11. Valet P, Tavernier G, Castan-Laurell, Saulnier-Blache JS, Langin D (2002) Understanding adipose tissue development from transgenic animal models. J Lipid Res 43:835-860

12. Ingalls AM, Dickie MM, Snell GD (1950) Obese, a new mutation in the mouse. J Hered 41:317-318

13. Hummel KP, Dickie MM, Coleman DL (1966) Diabetes, a new mutation in the mouse. Science 153:1127-1128

14. Chen H, Charlat O, Tartaglia LA et al. (1996) Evidence that thediabetes gene encodes the leptin receptor : identification of the mutation in the leptin receptor gene in $\mathrm{db} / \mathrm{db}$ mice. Cell 84:491-495

15. Masuzaki H, Paterson J, Shinyama H et al. (2001) A transgenic model of visceral obesity and the metabolic syndrome. Science 294:2166-2170

16. Tecott LH, Sun LM, Akana SF et al. (1995) Eating disorder and epilepsy in mice lacking 5-HT2c serotonin receptors. Nature 374:542-546

17. Kawaguchi N, Xu X, Tajima R et al. (2002) ADAM 12 protease induces adipogenesis in transgenic mice. Am J Pathol 160:1895-1903

18. Graham M, Shutter JR, Sarmiento U, Sarosi I, Stark KL (1997) Overexpression ofAgrt leads to obesity in transgenic mice. Nat Genet 17:273-274

19. Massiera F, Bloch-Faure M, Ceiler D et al. (2001) Adipose angiotensinogen is involved in adipose tissue growth and blood pressure regulation. FASEB J 15:2727-2729

20. Jones ME, Thorburn AW, Britt KL et al. (2000) Aromatase-deficient (ArKO) mice have a phenotype of increased adiposity. Proc Natl Acad Sci USA 97:12735-12740

21. Cuénot L (1905) Les races pures et leur combinaisons chez les souris. Arch Zool Expér Génér 3:123-132 
22. Wolff GL, Roberts DW, Mountjoy KG (1999) Physiological consequences of ectopicagouti gene expression: the yellow obese mouse syndrome. Physiol Genomics 1:151-163

23. Ohki Hamazaki H, Watase K, Yamamoto K et al. (1997) Mice lacking bombesin receptor subtype-3 develop metabolic defects and obesity. Nature 390:165-169

24. Fain JN, Ballou LR, Bahouth SW (2001) Obesity is induced in mice heterozygous for cyclooxygenase-2. Prostaglandins Other Lipid Mediat 65:199-209

25. Coleman DL, Eicher EM (1990) Fat (fat) and tubby (tub): two autosomal recessive mutations causing obesity syndromes in the mouse. J Hered 81:424-427

26. Naggert JK, Fricker LD, Varlamov O et al. (1995) Hyperproinsulinaemia in obesefat/fat mice associated with a carboxypeptidase $\mathrm{E}$ mutation which reduces enzyme activity. Nat Genet 10:135-142

27. Zucker LM, Zucker TF (1961) Fatty, a new mutation in the rat. J Hered 52:275-278

28. Chua SC Jr, Chung WK, Wu Peng XS et al. (1996) Phenotypes of mousediabetes and rat fatty due to mutations in the OB (leptin) receptor. Science 271:994-996

29. Takaya K, Ogawa Y, Hiraoka J et al. (1996) Nonsense mutation of leptin receptor in the obese spontaneously hypertensive Koletsky rat. Nat Genet 14:130-131

30. Kernie SG, Liebl DJ, Parada LF (2000) BDNF regulates eating behavior and locomotor activity in mice. EMBO J 19:1290-1300

31. Danilovich N, Babu PS, Xing W, Gerdes M, Krishnamurthy H, Sairam MR (2000) Estrogen deficiency, obesity, and skeletal abnormalities in follicle-stimulating hormone receptor knockout (FORKO) female mice. Endocrinology 141:4295-4308

32. Shepherd PR, Gnudi L, Tozzo E, Yang H, Leach F, Kahn BB (1993) Adipose cell hyperplasia and enhanced glucose disposal in transgenic mice overexpressing GLUT4 selectively in adipose tissue. J Biol Chem 268:22243-22246

33. Cai A, Hyde JF (1999) The human growth hormone-releasing hormone transgenic mouse as a model of modest obesity: differential changes in leptin receptor (OBR) gene expression in the anterior pituitary and hypothalamus after fasting and OBR localization in somatotrophs. Endocrinology 140:3609-3614

34. Dong ZM, Gutierrez-Ramos JC, Coxon A, Mayadas TN, Wagner DD (1997) A new class of obesity genes encodes leukocyte adhesion receptors. Proc Natl Acad Sci USA 94:7526-7530

35. Wallenius V, Wallenius K, Ahren B et al. (2002) Interleukin-6-deficient mice develop mature-onset obesity. Nat Med 8:75-79

36. Withers DJ, Gutierrez JS, Towery H et al. (1998) Disruption of IRS-2 causes type 2 diabetes in mice. Nature 391:900-904

37. Burks DJ, de Mora JF, Schubert M et al. (2000) IRS-2 pathways integrate female reproduction and energy homeostasis. Nature 407:377-382

38. Donahue LR, Beamer WG (1993) Growth hormone deficiency in 'little' mice results in aberrant body composition, reduced insulin-like growth factor-I and insulin-like growth factor-binding protein-3 (IGFBP-3), but does not affect IGFBP-2, -1 or -4. J Endocrinol 136:91-104

39. Chen AS, Marsh DJ, Trumbauer ME et al. (2000) Inactivation of the mouse melanocortin-3 receptor results in increased fat mass and reduced lean body mass. Nat Genet 26:97-102

40. Butler AA, Kesterson RA, Khong K et al. (2000) A unique metabolic syndrome causes obesity in the melanocortin-3 receptor-deficient mouse. Endocrinology 141:3518-3521
41. Huszar D, Lynch CA, Fairchild Huntress V et al. (1997) Targeted disruption of the melanocortin-4 receptor results in obesity in mice. Cell 88:131-141

42. Brüning JC, Michael MD, Winnay JN et al. (1998) A muscle-specific insulin receptor knockout exhibits features of the metabolic syndrome of NIDDM without altering glucose tolerance. Mol Cell 2:559-569

43. Beattie JH, Wood AM, Newman AM et al. (1998) Obesity and hyperleptinemia in metallothionein (-I and -II) null mice. Proc Natl Acad Sci USA 95:358-363

44. Good DJ, Porter FD, Mahon KA, Parlow AF, Westphal H, Kirsch IR (1997) Hypogonadism and obesity in mice with a targeted deletion of theNhlh2 gene. Nat Genet 15:397401

45. Brüning JC, Gautam D, Burks DJ et al. (2000) Role of brain insulin receptor in control of body weight and reproduction. Science 289:2122-2125

46. Uysal KT, Scheja L, Wiesbrock SM, Bonner-Weir S, Hotamisligil GS (2000) Improved glucose and lipid metabolism in genetically obese mice lacking aP2. Endocrinology 141:3388-3396

47. Cohen P, Zhao C, Cai X et al. (2001) Selective deletion of leptin receptor in neurons leads to obesity. J Clin Invest 108:1113-1121

48. Kawano K, Hirashima T, Mori S, Saitoh Y, Kurosumi M, Natori T (1992) Spontaneous long-term hyperglycemic rat with diabetic complications. Otsuka Long-Evans Tokushima Fatty (OLETF) strain. Diabetes 41:14221428

49. Yaswen L, Diehl N, Brennan MB, Hochgeschwender U (1999) Obesity in the mouse model of pro-opiomelanocortin deficiency responds to peripheral melanocortin. Nat Med 5:1066-1070

50. Costet P, Legendre C, More J, Edgar A, Galtier P, Pineau T (1998) Peroxisome proliferator-activated receptor $\alpha$-isoform deficiency leads to progressive dyslipidemia with sexually dimorphic obesity and steatosis. J Biol Chem 273:29577-29585

51. Majdic G, Young M, Gomez-Sanchez E et al. (2002) Knockout mice lacking steroidogenic factor 1 are a novel genetic model of hypothalamic obesity. Endocrinology 143:607-614

52. Michaud JL, Boucher F, Melnyk A et al. (2001) Sim1 haploinsufficiency causes hyperphagia, obesity and reduction of the paraventricular nucleus of the hypothalamus. Hum Mol Genet 10:1465-1473

53. Reizes O, Lincecum J, Wang Z et al. (2001) Transgenic expression of syndecan-1 uncovers a physiological control of feeding behavior by syndecan-3. Cell 106:105-116

54. Udy GB, Towers RP, Snell RG et al. (1997) Requirement of STAT5b for sexual dimorphism of body growth rates and liver gene expression. Proc Natl Acad Sci USA 94:7239-7244

55. Saltó C, Kindblom JM, Johansson C et al. (2001) Ablation of TRa2 and a concomitant overexpression of a1 yields a mixed hypo- and hyperthyroid phenotype in mice. Mol Endocrinol 15:2115-2128

56. Pepin MC, Pothier F, Barden N (1992) Impaired type II glucocorticoid-receptor function in mice bearing antisense RNA transgene. Nature 355:725-728

57. Lowell BB, Susulic VS, Hamann A et al. (1993) Development of obesity in transgenic mice after genetic ablation of brown adipose tissue. Nature 366:740-742

58. Kushi A, Sasai H, Koizumi H, Takeda N, Yokoyama M, Nakamura M (1998) Obesity and mild hyperinsulinemia found in neuropeptide Y-Y1 receptor-deficient mice. Proc Natl Acad Sci USA 95:15659-15664 
59. Naveilhan P, Hassani H, Canals JM et al. (1999) Normal feeding behavior, body weight and leptin response require the neuropeptide Y Y2 receptor. Nat Med 5:1188-1193

60. Sainsbury A, Schwarzer C, Couzens M et al. (2002) Y4 receptor knockout rescues fertility inob/ob mice. Genes Dev 16:1077-1088

61. Marsh DJ, Hollopeter G, Kafer KE, Palmiter RD (1998) Role of the Y5 neuropeptide Y receptor in feeding and obesity. Nat Med 4:718-721

62. Heine PA, Taylor JA, Iwamoto GA, Lubahn DB, Cooke PS (2000) Increased adipose tissue in male and female estrogen receptor- $\alpha$ knockout mice. Proc Natl Acad Sci USA 97:12729-12734

63. Susulic VS, Frederich RC, Lawitts J et al. (1995) Targeted disruption of the $\beta 3$-adrenergic receptor gene. J Biol Chem 270:29483-29492

64. Cohen P, Miyazaki M, Socci ND, et al. (2002) Role for stearoyl-CoA desaturase-1 in leptin-mediated weight loss. Science 297:240-243

65. Abu-Elheiga L, Matzuk MM, Abo-Hashema KA, Wakil SJ (2001) Continuous fatty acid oxidation and reduced fat storage in mice lacking acetyl-CoA carboxylase 2. Science 291:2613-2616

66. Maltais LJ, Lane PW, Beamer WG (1984) Anorexia, a recessive mutation causing starvation in preweanling mice. J Hered 75:468-472

67. Shimomura I, Hammer RE, Richardson JA et al. (1998) Insulin resistance and diabetes mellitus in transgenic mice expressing nuclear SREBP-1c in adipose tissue: model for congenital generalized lipodystrophy. Genes Dev 12:3182-3194

68. Kopecky J, Clarke G, Enerbäck S, Spiegelman B, Kozak LP (1995) Expression of the mitochondrial uncoupling protein gene from the aP2 gene promoter prevents genetic obesity. J Clin Invest 96:2914-2923

69. Moitra J, Mason MM, Olive M et al. (1998) Life without white fat: a transgenic mouse. Genes Dev 12:3168-3181

70. Murray I, Havel PJ, Sniderman AD, Cianflone K (2000) Reduced body weight, adipose tissue, and leptin levels despite increased energy intake in female mice lacking acylation-stimulating protein. Endocrinology 141:1041-1049

71. Razani B, Combs TP, Wang XB et al. (2002) Caveolin1-deficient mice are lean, resistant to diet-induced obesity, and show hypertriglyceridemia with adipocyte abnormalities. J Biol Chem 277:8635-8647

72. Wang ND, Finegold MJ, Bradley A et al. (1995) Impaired energy homeostasis in $\mathrm{C} / \mathrm{EBP} \alpha$ knockout mice. Science 269:1108-1112

73. Tanaka T, Yoshida N, Kishimoto T, Akira S (1997) Defective adipocyte differentiation in mice lacking the $\mathrm{C} / \mathrm{EBP} \beta$ and/or C/EBP $\delta$ gene. EMBO J 16:7432-7443

74. Yamauchi T, Oike Y, Kamon J et al. (2002) Increased insulin sensitivity despite lipodystrophy inCrebbp heterozygous mice. Nat Genet 30:221-226

75. Tsukiyama-Kohara K, Poulin F, Kohara M et al. (2001) Adipose tissue reduction in mice lacking the translational inhibitor 4E-BP1. Nat Med 7:1128-1132

76. Blüher M, Michael MD, Peroni OD et al. (2002) Adipose tissue selective insulin receptor knockout protects against obesity and obesity-related glucose intolerance. Dev Cell 3:25-38

77. Cederberg A, Gronning LM, Ahren B, Tasken K, Carlsson P, Enerback S (2001)FOXC2 is a winged helix gene that counteracts obesity, hypertriglyceridemia, and diet-induced insulin resistance. Cell 106:563-573

78. Shuto Y, Shibasaki T, Otagiri A et al. (2002) Hypothalamic growth hormone secretagogue receptor regulates growth hormone secretion, feeding, and adiposity. J Clin Invest 109:1429-1436
79. Katz EB, Stenbit AE, Hatton K, DePinho R, Charron MJ (1995) Cardiac and adipose tissue abnormalities but not diabetes in mice deficient in GLUT4. Nature 377:151-155

80. Kellendonk C, Eiden S, Kretz O et al. (2002) Inactivation of the GR in the nervous system affects energy accumulation. Endocrinology 143:2333-2340

81. Anand A, Chada K (2000) In vivo modulation ofHmgic reduces obesity. Nat Genet 24:377-380

82. Sainsbury A, Schwarzer C, Couzens M et al. (2002) Important role of hypothalamic Y2 receptors in body weight regulation revealed in conditional knockout mice. Proc Natl Acad Sci USA 18:8938-8943

83. Hirsch E, Irikura VM, Paul SM, Hirsh D (1996) Functions of interleukin 1 receptor antagonist in gene knockout and overproducing mice. Proc Natl Acad Sci USA 93:1100811013

84. Yamada M, Miyakawa T, Duttaroy A et al. (2001) Mice lacking the M3 muscarinic acetylcholine receptor are hypophagic and lean. Nature 410:207-212

85. Shimada M, Tritos NA, Lowell BB, Flier JS, Maratos Flier E (1998) Mice lacking melanin-concentrating hormone are hypophagic and lean. Nature 396:670-674

86. Marsh DJ, Weingarth DT, Novi DE et al. (2002) Melaninconcentrating hormone 1 receptor-deficient mice are lean, hyperactive, and hyperphagic and have altered metabolism. Proc Natl Acad Sci USA 99:3240-3245

87. Ibrahimi A, Bonen A, Blinn WD et al. (1999) Musclespecific overexpression of FAT/CD36 enhances fatty acid oxidation by contracting muscle, reduces plasma triglycerides and fatty acids, and increases plasma glucose and insulin. J Biol Chem 274:26761-26766

88. Eto K, Tsubamoto Y, Terauchi Y et al. (1999) Role of NADH shuttle system in glucose-induced activation of mitochondrial metabolism and insulin secretion. Science 283:981-985

89. McPherron AC, Lee SJ (2002) Suppression of body fat accumulation in myostatin-deficient mice. J Clin Invest 109:595-601

90. Clouthier DE, Comerford SA, Hammer RE (1997) Hepatic fibrosis, glomerulosclerosis, and a lipodystrophy-like syndrome in PEPCK-TGF- $\beta 1$ transgenic mice. J Clin Invest 100:2697-2713

91. Martínez-Botas J, Anderson JB, Tessier D et al. (2000) Absence of perilipin results in leanness and reverses obesity inLeprdb/db mice. Nat Genet 26:474-479

92. Tansey JT, Sztalryd C, Gruia Gray J et al. (2001) Perilipin ablation results in a lean mouse with aberrant adipocyte lipolysis, enhanced leptin production, and resistance to diet-induced obesity. Proc Natl Acad Sci USA 98:64946499

93. Ueno N, Inui A, Iwamoto M et al. (1999) Decreased food intake and body weight in pancreatic polypeptide-overexpressing mice. Gastroenterology 117:1427-1432

94. Cummings DE, Brandon EP, Planas JV, Motamed K, Idzerda RL, McKnight GS (1996) Genetically lean mice result from targeted disruption of the RII $\beta$ subunit of protein kinase A. Nature 382:622-626

95. Fain JN, Ihle JH, Bahouth SW (1999) Stimulation of lipolysis but not of leptin release by growth hormone is abolished in adipose tissue from Stat5a and b knockout mice. Biochem Biophys Res Commun 263:201-205

96. Ventre J, Doebber T, Wu M et al. (1997) Targeted disruption of the tumor necrosis factor- $\alpha$ gene: metabolic consequences in obese and nonobese mice. Diabetes 46:1526-1531

97. Ogawa Y, Masuzaki H, Hosoda K et al. (1999) Increased glucose metabolism and insulin sensitivity in transgenic skinny mice overexpressing leptin. Diabetes 48:1822-1829 
98. Clapham JC, Arch JR, Chapman H et al. (2000) Mice overexpressing human uncoupling protein-3 in skeletal muscle are hyperphagic and lean. Nature 406:415-418

99. Bernal-Mizrachi C, Weng S, Li B et al. (2002) Respiratory uncoupling lowers blood pressure through a leptindependent mechanism in genetically obese mice. Arterioscler Thromb Vasc Biol 22:961-968

100. Li B, Nolte LA, Ju J-S et al. (2000) Skeletal muscle respiratory uncoupling prevents diet-induced obesity and insulin resistance in mice. Nat Med 6:1115-1120

101. Hahm S, Mizuno TM, Wu TJ et al. (1999) Targeted deletion of theVgf gene indicates that the encoded secretory peptide precursor plays a novel role in the regulation of energy balance. Neuron 23:537-548

102. Frykman PK, Brown MS, Yamamoto T, Goldstein JL, Herz J (1995) Normal plasma lipoproteins and fertility in gene-targeted mice homozygous for a disruption in the gene encoding very low density lipoprotein receptor. Proc Natl Acad Sci USA 92:8453-8457

103. Massiera F, Seydoux J, Geloen A et al. (2001) Angiotensinogen-deficient mice exhibit impairment of diet-induced weight gain with alteration in adipose tissue development and increased locomotor activity. Endocrinology 142:5220-5225

104. Szczypka MS, Rainey MA, Palmiter RD (2000) Dopamine is required for hyperphagia inLepob/ob mice. Nat Genet 25:102-104

105. Smith SJ, Cases S, Jensen DR et al. (2000) Obesity resistance and multiple mechanisms of triglyceride synthesis in mice lackingDgat. Nat Genet 25:87-90

106. Fajas L, Landsberg RL, Huss-Garcia Y, Sardet C, Lees JA, Auwerx J (2002) E2Fs regulate adipocyte differentiation. Dev Cell 3:39-49

107. Miyawaki K, Yamada Y, Ban N, et al. (2002) Inhibition of gastric inhibitory polypeptide signaling prevents obesity. Nat Med 8:738-742

108. Scrocchi LA, Drucker DJ (1998) Effects of aging and a high fat diet on body weight and glucose tolerance in glucagon-like peptide-1 receptor-/- mice. Endocrinology 139:3127-3132

109. Weinstock PH, Levak-Frank S, Hudgins LC et al. (1997) Lipoprotein lipase controls fatty acid entry into adipose tissue, but fat mass is preserved by endogenous synthesis in mice deficient in adipose tissue lipoprotein lipase. Proc Natl Acad Sci USA 94:10261-10266

110. Yahagi N, Shimano H, Hasty AH et al. (2002) Absence of sterol regulatory element-binding protein-1 (SREBP-1) ameliorates fatty livers, but not obesity or insulin resistance inLepob/Lepob mice. J Biol Chem 277:19353-19357

111. Dinulescu DM, Fan W, Boston BA et al. (1998)Mahogany (mg) stimulates feeding and increases basal metabolic rate independent of its suppression of agouti. Proc Natl Acad Sci USA 95:12707-12712

112. Erickson JC, Hollopeter G, Palmiter RD (1996) Attenuation of the obesity syndrome ofob/ob mice by the loss of neuropeptide Y. Science 274:1704-1707

113. Schreyer SA, Chua SC, Jr., LeBoeuf RC (1998) Obesity and diabetes in TNF- $\alpha$ receptor-deficient mice. J Clin Invest 102:402-411

114. Schafer K, Fujisawa K, Konstantinides S, Loskutoff DJ (2001) Disruption of the plasminogen activator inhibitor 1 gene reduces the adiposity and improves the metabolic profile of genetically obese and diabeticob/ob mice. FASEB J 15:1840-1842

115. Kubota N, Terauchi Y, Miki H et al. (1999) PPAR $\gamma$ mediates high-fat diet-induced adipocyte hypertrophy and insulin resistance. Mol Cell 4:597-609
116. Elchebly M, Payette P, Michaliszyn E et al. (1999) Increased insulin sensitivity and obesity resistance in mice lacking the protein tyrosine phosphatase-1B gene. Science 283:1544-1548

117. Cheng A, Uetani N, Simoncic PD et al. (2002) Attenuation of leptin action and regulation of obesity by protein tyrosine phosphatase 1B. Dev Cell 2:497-503

118. Goudriaan JR, Tacken PJ, Dahlmans VE et al. (2001) Protection from obesity in mice lacking the VLDL receptor. Arterioscler Thromb Vasc Biol 21:1488-1493

119. Soloveva V, Graves RA, Rasenick MM, Spiegelman BM, Ross SR (1997) Transgenic mice overexpressing the $\beta 1$-adrenergic receptor in adipose tissue are resistant to obesity. Mol Endocrinol 11:27-38

120. Flier JS, Maratos-Flier E (1998) Obesity and the hypothalamus: novel peptides for new pathways. Cell 92:437440

121. Schwartz MW, Woods SC, Porte D Jr, Seeley RJ, Baskin DG (2000) Central nervous system control of feeding. Nature 404:661-671

122. Heisler LK, Cowley MA, Tecott LH et al. (2002) Activation of central melanocortin pathways by fenfluramine. Science 297:609-611

123. Rosen ED, Walkey CJ, Puigserver P, Spiegelman BM (2000) Transcriptional regulation of adipogenesis. Genes Dev 14:1293-1307

124. Mauvais-Jarvis F, Kulkarni RN, Kahn CR (2002) Knockout models are useful tools to dissect the pathophysiology and genetics of insulin resistance. Clin Endocrinol 57:1-9

125. Kulkarni RN, Brüning JC, Winnay JN, Postic C, Magnuson MA, Kahn CR (1999) Tissue-specific knockout of the insulin receptor in pancreatic beta cells creates an insulin secretory defect similar to that in type 2 diabetes. Cell 96:329-339

126. Mauvais-Jarvis F, Virkamaki A, Michael MD, et al. (2000) A model to explore the interaction between muscle insulin resistance and beta-cell dysfunction in the development of type 2 diabetes. Diabetes 49:2126-2134

127. Michael MD, Kulkarni RN, Postic C, Previs SF, Shulman GI, Magnuson MA (2000) Loss of insulin signaling in hepatocytes leads to severe insulin resistance and progressive hepatic dysfunction. Mol Cell 6:87-97

128. Guerra C, Navarro P, Valverde AM et al. (2001) Brown adipose tissue-specific insulin receptor knockout shows a phenotype without insulin resistance. J Clin Invest 108:1205-1213

129. Mathews ST, Singh GP, Ranalletta M, et al. (2002) Improved insulin sensitivity and resistance to weight gain in mice null for theAhsg gene. Diabetes 51:2450-2458

130. Ikeda A, Chang K-T, Matsumoto Y, et al. (1998) Obesity and insulin resistance in human growth hormone transgenic rats. Endocrinology 139:3057-3063

131. Rask E, Olsson T, Söderberg S et al. (2001) Tissuespecific dysregulation of cortisol metabolism in human obesity. J Clin Endocrinol Metab 86:1418-1421

132. Livingstone DEW, Jones GC, Smith K, Andrew R, Kenyon CJ, Walker BR (2000) Understanding the role of glucocorticoids in obesity: tissue-specific alterations of corticosterone metabolism in obese Zucker rats. Endocrinology 141:560-563

133. Ling C, Hellgren G, Gebre-Medhin M, et al. (2000) Prolactin (PRL) receptor gene expression in mouse adipose tissue: increases during lactation in PRL-transgenic mice. Endocrinology 141:3564-3572

134. Freemark M, Fleenor D, Driscoll P, Binart N, Kelly PA (2001) Body weight and fat deposition in prolactin receptor-deficient mice. Endocrinology 142:532-537 
135. Havel PJ (2001) Peripheral signals conveying metabolic information to the brain: short-term and long-term regulation of food intake and energy homeostasis. Exp Biol Med 226:963-977

136. Raguso C, McCullough AJ (2000) Leptin and the gastrointestinal tract. Curr Opin Gastroenterol 16:160-165

137. Kojima M, Hosoda H, Date Y, Nakazato M, Matsuo H, Kangawa K (1999) Ghrelin is a growth-hormone-releasing acylated peptide from stomach. Nature 402:656-660

138. Mucciolo G, Tshöp M, Papotti M, Deghenghi R, Heiman M, Ghigo E (2002) Neuroendocrine and peripheral activities of ghrelin: implications in metabolism and obesity. Eur J Pharmacol 440:235-254

139. Yip RGC, Wolfe MM (2000) GIP biology and fat metabolism. Life Sci 66:91-103

140. Miyawaki K, Yamada Y, Yano H et al. (1999) Glucose intolerance caused by a defect in the entero-insular axis: a study in gastric inhibitory polypeptide receptor knockout mice. Proc Natl Acad Sci USA 96:14843-14847

141. Lafontan M, Berlan M (1993) Fat cell adrenergic receptors and the control of white and brown fat cell function. J Lipid Res 34:1057-1091

142. Bachman ES, Dhillon H, Zhang C-Y et al. (2002) $\beta A R$ signaling required fot diet-induced thermogenesis and obesity resistance. Science 297:843-845

143. Valet PD, Grujic J, Wade M et al. (2000) Expression of human alpha 2-adrenergic receptors in adipose tissue of beta 3-adrenergic receptor-deficient mice promotes dietinduced obesity. J Biol Chem 275:34797-34802

144. Yu S, Yu D, Lee E et al. (1998) Variable and tissuespecific hormone resistance in heterotrimeric Gs protein $\alpha$-subunit (Gs $\alpha$ ) knockout mice is due to tissue-specific imprinting of the Gs $\alpha$ gene. Proc Natl Acad Sci USA 95:8715-8720

145. Yu S, Gavrilova O, Chen $\mathrm{H}$ et al. (2000) Paternal versus maternal transmission of a stimulatory $G$ protein $\alpha$-subunit knockout produces opposite effects on energy metabolism. J Clin Invest 105:615-623

146. Moxham CM, Malbon CC (1996) Insulin action impaired by deficiency of the G-protein subunit Gio2. Nature 379:840-844

147. Tao J, Malbon CC, Wang H (2001) Goi2 enhances insulin signalling via suppression of protein-tyrosine phosphatase 1B. J Biol Chem 276:39705-39712

148. Galvin-Parton PA, Chen X, Moxham CM, Malbon CC (1997) Induction of Goq-specific antisense RNA in vivo causes increased body mass and hyperadiposity. J Biol Chem 272:4335-4341

149. Arner P (2000) Hunting for human obesity genes? Look in the adipose tissue. Int J Obes 24: S57-S62

150. Ioffe E, Moon B, Connolly E, Friedman JM (1998) Abnormal regulation of the leptin gene in the pathogenesis of obesity. Proc Natl Acad Sci USA 95:11852-11857

151. Qiu J, Ogus S, Lu R, Chehab FF (2001) Transgenic mice overexpressing leptin accumulate adipose mass at an older, but not younger age. Endocrinology 142:348-358

152. Uysal KT, Wiesbrock SM, Marino MW, Hotamisligil GS (1997) Protection from obesity-induced insulin resistance in mice lacking TNF- $\alpha$ function. Nature 389:610-614

153. Uysal KT, Wiesbrock SM, Hotamisligil GS (1998) Functional analysis of tumor necrosis factor (TNF) receptors in TNF- $\alpha$ mediated insulin resistance in genetic obesity. Endocrinology 139:4832-4838

154. Nisoli E, Briscini L, Giordano A et al. (2000) Tumor necrosis factor $\alpha$ mediates apoptosis of brown adipocytes and defective brown adipocyte function in obesity. Proc Natl Acad Sci USA 97:8033-8038
155. Ukkola O (2002) Resistin — a mediator of obesity-associated insulin resistance or an innocent bystander? Eur $\mathrm{J}$ Endocrinol 147:571-574

156. Berg AH, Combs TP, Scherer PE (2002) ACRP30/adiponectin: an adipokine regulating glucose and lipid metabolism. Trends Endocrinol Metab 13:84-89

157. Perreault M, Marette A (2001) Targeted disruption of inducible nitric-oxide synthase protects against obesitylinked insulin resistance in muscle. Nat Med 7:11381143

158. Duplain H, Burcelin R, Sartori C et al. (2001) Insulin resistance, hyperlipidemia and hypertension in mice lacking endothelial nitric oxide synthase. Circulation 104:342345

159. Shindo T, Kurihara H, Kuno K et al. (2000) ADAMTS-1: a metalloproteinase-disintegrin essential for normal growth, fertility, and organ morphology and function. J Clin Invest 105:1345-1352

160. Enerbäck S, Jacobsson A, Simpson EM et al. (1997) Mice lacking mitochondrial uncoupling protein are cold-sensitive but not obese. Nature 387:90-94

161. Kopecky J, Hodny Z, Rossmeisl M, Syrovy I, Kozak LP (1996) Reduction of dietary obesity in aP2-Ucp transgenic mice: physiology and adipose tissue distribution. Am J Physiol 270: E768-E775

162. Tsao T-S, Stenbit AE, Li J et al. (1997) Muscle-specific transgenic complementation of GLUT4-deficient mice. Effects on glucose but not lipid metabolism. J Clin Invest 100:671-677

163. Zisman et al. (2000) Targeted disruption of the glucose transporter 4 selectively in muscle causes insulin resistance and glucose intolerance. Nat Med 6:924-928

164. Stenbit AE, Tsao T-S, Li J et al. (1997) GLUT4 heterozygous knockout mice develop muscle insulin resistance and diabetes. Nat Med 3:1096-1101

165. Abel ED, Peroni O, Kim JK et al. (2001) Adipose-selective targeting of Glut4 gene impairs insulin action in muscle and liver. Nature 409:729-733

166. Jong MC, Gijbels MJ, Dahlmans VE et al. (1998) Hyperlipidemia and cutaneous abnormalities in transgenic mice overexpressing human apolipoprotein $\mathrm{C} 1$. J Clin Invest 101:145-152

167. Castellani LW, Goto AM, Lusis AJ (2001) Studies with apolipoprotein A-II transgenic mice indicate a role for HDLs in adiposity and insulin resistance. Diabetes 50:643-651

168. Weinstock PH, Bisgaier CL, Aalto-Setälä et al. (1995) Severe hypertriglyceridemia, reduced high density lipoprotein, and neonatal death in lipoprotein lipase knockout mice. Mild hypertriglyceridemia with impaired low density lipoprotein clearance in heterozygotes. J Clin Invest 96:2555-2568

169. Chen HC, Farese RV Jr (2002) Fatty acids, triglycerides, and glucose metabolism: recent insights from knockout mice. Curr Opin Clin Nutr Metab Care 5:359-363

170. Febbraio M, Abumrad NA, Hajjar DP et al. (1999) A null mutation in CD36 reveals an important role in fatty acid and lipoprotein metabolism. J Biol Chem 274:1905519062

171. Cases S, Stone S, Zhou P et al. (2001) Cloning of DGAT2, a second mammalian diacylglycerol acyltransferase, and related family members. J Biol Chem 276:38870-38876

172. Tomlinson E, Fu L, John L et al. (2002) Transgenic mice expressing human fibroblast growth factor-19 display increased metabolic rate and decreased adiposity. Endocrinology 143:1741-1747 
173. Osuga JS, Ishibashi S, Oka T et al. (2000) Targeted disruption of hormone-sensitive lipase results in male sterility and adipocyte hypertrophy, but not in obesity. Proc Natl Acad Sci USa 97:787-792

174. Haemmerle G, Zimmermann R, Strauss JG et al. (2002) Hormone-sensitive lipase deficiency in mice changes the plasma lipid profile by affecting the tissue-specific expression pattern of lipoprotein lipase in adipose tissue and muscle. J Biol Chem 277:12946-12952

175. Kraemer FB, Shen W-J (2002) Hormone-sensitive lipase: control of intracellular tri-(di-)acylglycerol and cholesteryl ester hydrolysis. J Lipid Res 43:15851594

176. Hotamisligil GS, Johnson RS, Distel RJ, Ellis R, Papaioannou VE, Spiegelman BM (1996) Uncopupling of obesity from insulin resistance through a targeted mutation inaP2, the adipocyte fatty acid binding protein. Science 274:1377-1379
177. Coe NR, Simpson MA, Bernlohr DA (1999) Targeted disruption of the adipocyte lipid-binding ( $\mathrm{aP} 2$ protein) gene impairs fat cell lipolysis and increases cellular fatty acid levels. J Lipid Res 40:967-972

178. Shaughnessy S, Smith ER, Kodukula S, Storch J, Fried SK (2000) Adipocyte metabolism in adipocyte fatty acid binding protein knockout (aP2-/-) mice after short-term high-fat feeding: functional compensation by keratinocyte fatty acid binding protein. Diabetes 49:904-911

179. Kozak LP, Kozak UC, Clarke GT (1991) Abnormal brown and white fat development in transgenic mice overexpressing glycerol 3-phosphate dehydrogenase. Genes Dev 5:2256-2264

180. Hammond LE, Gallagher PA, Wang S et al. (2002) Mitochondrial glycerol-3-phosphate acyltransferase-deficient mice have reduced weight and liver triacylglycerol content and altered glycerolipid fatty acid composition. Mol Cell Biol 22:8204-8214 